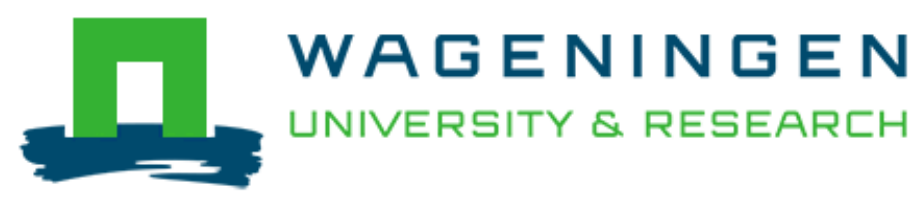

The effect of gas to liquid ratio on carbon dioxide removal and heat loss across a forced ventilated trickling filter

Karimi, D., Eding, E., Aarnink, A. J. A., Groot Koerkamp, P., \& Verreth, J.

This is a "Post-Print" accepted manuscript, which has been Published in "Aquacultural Engineering"

This version is distributed under a non-commercial no derivatives Creative Commons (C) $(\mathcal{\Theta \Theta}$ (CC-BY-NC-ND) user license, which permits use, distribution, and reproduction in any medium, provided the original work is properly cited and not used for commercial purposes. Further, the restriction applies that if you remix, transform, or build upon the material, you may not distribute the modified material.

Please cite this publication as follows:

Karimi, D., Eding, E., Aarnink, A. J. A., Groot Koerkamp, P., \& Verreth, J. (2020). The effect of gas to liquid ratio on carbon dioxide removal and heat loss across a forced ventilated trickling filter. Aquacultural Engineering, 88, [102042].

https://doi.org/10.1016/j.aquaeng.2019.102042

You can download the published version at:

https://doi.org/10.1016/j.aquaeng.2019.102042 


\title{
The effect of gas to liquid ratio on carbon dioxide removal and heat loss across a forced ventilated trickling filter.
}

Davood Karimi $^{\mathrm{a}, \mathrm{b}}$,, Ep Eding ${ }^{\mathrm{a}}$, Andre J.A. Aarnink ${ }^{\mathrm{b}}$, Peter Groot Koerkamp ${ }^{\mathrm{b}}$, Johan Verreth ${ }^{\mathrm{a}}$

\footnotetext{
${ }^{a}$ Aquaculture and Fisheries Group, Department of Animal Sciences, Wageningen University and Research, PO Box 338, 6700AH Wageningen, The Netherlands.

${ }^{\mathrm{b}}$ Farm Technology Group, Department of Plant Sciences, Wageningen University and Research, P.O. Box 16, 6700 AA

Wageningen, The Netherlands
}

\begin{abstract}
:
The objective of this study was to investigate the effect of the gas : liquid ratio (GLR) on carbon dioxide removal and heat loss across a forced-ventilated trickling filter (TF) used as bioreactor. The effect of 8 different GLRs (1.2 - 15.7) on carbon dioxide removal and heat loss from water passing a TF were tested in random order. The TF was part of a pilot scale fresh water intensive recirculating aquaculture system and had a media bed height of $1.8 \mathrm{~m}$, a diameter of $0.9 \mathrm{~m}$, a specific surface area of $200 \mathrm{~m}^{2} / \mathrm{m}^{3}$ and was operated at a fixed hydraulic surface load of $9.42 \mathrm{~m}^{3} /\left(\mathrm{m}^{2} . \mathrm{h}\right)$, a mean inlet water temperature of 27.0 $27.5^{\circ} \mathrm{C}$, and a mean inlet $\mathrm{pH}$ ranging from $7.02-7.12$. For each GLR, $\mathrm{CO}_{2}$ removal from water was calculated from $\mathrm{CO}_{2}$ measurements in the inlet and outlet air of the TF using an online infrared probe (developed for agriculture and greenhouses) and from 12 water measurements done once every $3 \mathrm{~h}$ during 2 subsequent days. The water inlet $\mathrm{CO}_{2}$ concentrations varied between $4.5-9.0 \mathrm{mg} / \mathrm{L}$ (calculated from total inorganic carbon and $\mathrm{pH}$ ). The results showed that the $\mathrm{CO}_{2}$ removal from water to the air in a TF increased from $3.1 \mathrm{mg} / \mathrm{L}$ at a GLR of 1 to $6.1 \mathrm{mg} / \mathrm{L}$ for a GLR of 15 . The relationship between GLR and $\mathrm{CO}_{2}$ removal could be described as an asymptotic curve with the following equation $\mathrm{CO}_{2}$ removal from water $\left(\frac{\mathrm{mg}}{\mathrm{L}}\right)=6.44-5.82\left(0.648^{G L R}\right)\left(\mathrm{R}^{2}=0.91\right)$. A linear relation between total heat loss across the TF and the applied GLRs showed an average total heat loss of $33.2 \mathrm{~kJ}$ per cubic meter of air for all GLRs. Of the total heat loss on average $91 \%$ was latent heat loss and $9 \%$ sensible heat loss. This study showed that: (1) GLRs above 5 will not result in significant additional $\mathrm{CO}_{2}$ removal; (2) energy loss at a GLR of 5 is, under our experimental conditions with a mean inlet air temperature of $22.6{ }^{\circ} \mathrm{C}$ and an mean inlet air relative humidity of $66.9 \%, 26.0 \mathrm{~kJ}$ per $\mathrm{g} \mathrm{CO}_{2}$ removed.
\end{abstract}

Keywords: Carbon dioxide stripping, Trickling filter, Nitrification, RAS, Forced ventilation, Degassing, Gas: Liquid ratio, Energy

${ }^{*}$ Corresponding author at: Aquaculture and Fisheries Group, Department of Animal Sciences, Wageningen University and Research, PO Box 338, 6700AH Wageningen, Netherlands. Tel.: +31 31748 5147; E-mail address: karimidv@gmail.com (D. Karimi). 


\section{Introduction}

In recirculating aquaculture systems (RAS) carbon dioxide $\left(\mathrm{CO}_{2}\right)$ produced by fish and microbiota can accumulate to high concentrations in the water, if not adequately removed or controlled by a water treatment unit (Eding et al., 2006; Fivelstad, 2013; Vinci et al., 1998). Chronic exposure of fish to high concentrations of $\mathrm{CO}_{2}$ can negatively impact growth, physiology and behaviour of fish (Ellis et al., 2017; Khan et al., 2018; Mota et al., 2019; Santos et al., 2013). Therefore $\mathrm{CO}_{2}$ concentrations need to be controlled at levels which do not affect fish performance. However, controlling $\mathrm{CO}_{2}$ at low concentrations in the culture tank volume is expensive and is recognised as one of the major production hurdles for intensive RAS (Khan et al., 2018) as: (1) fish performance is already negatively affected at relatively low $\mathrm{CO}_{2}$ concentrations (acted in seabass as chronic stressor at $7 \mathrm{mg} \mathrm{CO} / 1$ (Santos et al., 2013); juvenile Atlantic salmon show a linear decrease in specific growth rate in the range of $2.9-25$ mg CO $2 / \mathrm{L}$ (Khan et al., 2018; Mota et al., 2019); (2) welfare standards for rainbow trout and Atlantic salmon smolts are set at values: $<10 \mathrm{mg} \mathrm{CO}_{2} / \mathrm{L}$ and $<15 \mathrm{mg} \mathrm{CO}_{2} / \mathrm{L}$, respectively (RSPCA, 2018a, b); (3) fish respire large amounts of $\mathrm{CO}_{2}$ per $\mathrm{kg}$ feed intake (eel culture $536 \mathrm{~g} \mathrm{CO}_{2} / \mathrm{kg}$ feed (Heinsbroek and Kamstra, 1990); Atlantic salmon, $409 \mathrm{~g} \mathrm{CO}_{2} / \mathrm{kg}$ feed (Terjesen et al., 2013); Atlantic salmon smolts, $550 \mathrm{~g} \mathrm{CO}_{2} / \mathrm{kg}$ feed (Vinci et al., 2004)); (4) $\mathrm{CO}_{2}$ productions per $\mathrm{kg}$ feed might be higher (16 - 45\% higher for salmon smolt (Kvamme et al., 2018) when they are apparent $\mathrm{CO}_{2}$ productions (calculated from the $\mathrm{CO}_{2}$ concentration in the fish tank inlet and outlet) instead of true $\mathrm{CO}_{2}$ productions (calculated from the total inorganic carbonate carbon concentration in the fish tank inlet and outlet); (5) $\mathrm{CO}_{2}$ degassers do not operate at $100 \%$ removal efficiency but are designed/operated in the range of $40 \%$ $78 \%$ efficiency (Noble et al., 2012; Terjesen et al., 2013; Vinci et al., 2004), consequently large water flows per $\mathrm{kg}$ feed (approximately $50-140 \mathrm{~m}^{3}$ per $\mathrm{kg}$ feed per day) are required to maintain $\mathrm{CO}_{2}$ at or below maximum allowable concentrations of $10 \mathrm{mg} \mathrm{CO} / \mathrm{L}$ (RSPCA, 2018b; Terjesen et al., 2013; Vinci et al., 2004); (6) temporarily even higher flow rates are required (up to 1.6 times higher than the average flow for Atlantic salmon) to counteract $\mathrm{CO}_{2}$ accumulation due to diurnal variation in $\mathrm{CO}_{2}$ production (Kvamme et al., 2018). In addition fish production in intensive RAS is characterised by high fish densities (max densities: tilapia $80 \mathrm{~kg} / \mathrm{m}^{3}$, Atlantic salmon $85-100 \mathrm{~kg} / \mathrm{m}^{3}$; African catfish $>300 \mathrm{~kg} / \mathrm{m}^{3}$ (Murray, 2014) resulting in high feed loads and $\mathrm{CO}_{2}$ productions per unit of culture tank volume.

To control $\mathrm{CO}_{2}$-concentrations several studies presented experimental and theoretical data on factors affecting the treatment efficiency of $\mathrm{CO}_{2}$-degassing units for design purposes or to optimize/improve their performance (Colt and Bouck, 1984; Grace and Piedrahita, 1993, 1994; Hackney and Colt, 1982; Moran, 2010; Summerfelt et al., 2003; Summerfelt et al., 2000; Timmons, 2002; Timmons and Ebeling, 2010; Watten et al., 1991). $\mathrm{CO}_{2}$-degassing units studied in literature are mainly operated as separate treatment units in the water treatment train of a RAS and are operated at high hydraulic surface loads of 61-86 $\mathrm{m}^{3} / \mathrm{m}^{2} . \mathrm{h}$ (Timmons and Ebeling, 2010), $90 \mathrm{~m}^{3} / \mathrm{m}^{2}$.h (Terjesen et al., 2013) and $60-84 \mathrm{~m}^{3} / \mathrm{m}^{2} . \mathrm{h}$ to $100-250 \mathrm{~m}^{3} / \mathrm{m}^{2}$.h (Summerfelt, 2001). Degassing towers are operated at gas to liquid ratios (GLRs) of 5 - 10. In degassing towers random media (5 cm Norpac, Pall ${ }^{\mathrm{TM}}$ rings), structured media (Munters) and splash screens are used as packing media (Summerfelt et al., 2000).

In contrast to degassing units, trickling filters (TFs) in commercial RAS are designed to combine biofiltration and degassing and are operated at lower hydraulic surface loads of $2-33 \mathrm{~m}^{3} / \mathrm{m}^{2}$.h (Eding et al., 2006; Kamstra et al., 1998). Commercial TFs are loaded with the non-settleable/non-screenable metabolic waste in the range of 0.7-2.5 $\mathrm{kg}$ feed per $\mathrm{m}^{3}$ filter media per day (Díaz et al., 2012), 1.6 - 2.9 $\mathrm{kg}$ feed per $\mathrm{m}^{3}$ filter media per day (Kamstra et al., 1998) and are equipped with forced ventilation. Bionet (tubular, vertical flow) or crossflow media are frequently applied as TF media (Kamstra et al., 1998). A similar type of TF media when compared with Bionet is Bio-Blok (tubular, vertical flow) which was used by Moran (2010) in a $\mathrm{CO}_{2}$ degassing study using a $22.8 \mathrm{~m}^{3} / \mathrm{m}^{2} \cdot \mathrm{h}$. However, in contrast to what is reported in other studies, Moran (2010) did not find an improvement of the $\mathrm{CO}_{2}$ stripping 
efficiency at a gas liquid ratio of 4.6 when compared with 1 (without forced ventilation). To the best of our knowledge there are no studies which assessed the effect of gas : liquid ratios on $\mathrm{CO}_{2}$ degassing efficiency and heat loss across TFs under intensive culture conditions using Bionet (tubular, vertical structure) as packing media. This knowledge gap, and the growing interest of fish farmers in optimizing water quality and reducing energy use for the cultured fish were the motivation for the current study. Therefore in this study we investigated the effect of gas to liquid ratio on carbon dioxide removal and heat loss through a forced vented trickling filter operated under intensive fish culture conditions. African catfish was chosen as fish species as high fish densities and high waste loads (Total Ammonia Nitrogen (TAN) and organic matter) can easily be maintained on the trickling filter. This is a first study to collect data for the application of precision ventilation in farms applying trickling filters as bioreactor in order to control carbon dioxide concentration and reduce energy loss by forced ventilation through trickling filters.

\section{Materials and Methods}

\subsection{Experimental design}

In this study the effect of 8 different gas : liquid ratios (GLRs) on carbon dioxide removal and heat loss from water passing a trickling filter (bio-reactor) were tested in random order (Table 1). The used trickling filter was part of a pilot scale recirculating aquaculture system (RAS, Figure 1) and was supplied with a constant water flow of $6 \mathrm{~m}^{3} / \mathrm{h}$ (hydraulic surface load $226 \mathrm{~m}^{3} / \mathrm{m}^{2}$.d). To maintain relatively constant experimental conditions, i.e. constant fish metabolite production and metabolite concentrations during the 18 weeks experimental period, the RAS was operated at: a constant daily feed load (3 kg feed/d), continuously feeding using a belt feeder (24/d), a photoperiod of 24L:0D (hours Light : Dark) a fixed system make-up water supply $(700 \mathrm{~L} / \mathrm{d})$ and a constant $\mathrm{pH}(\mathrm{pH}=7)$. Prior to the start of the experiment, fish tanks were restocked and the system was allowed for one month to stabilize its levels of water conductivity $(\mu \mathrm{S} / \mathrm{cm})$ and nitrate. During this pre-experimental period, the GLR was maintained at 11. Experimental settings for each tested GLR were controlled for a period of 7 days of which the last 2 days were measurement days. The experiment was conducted in the water treatment hall of the $1900 \mathrm{~m}^{2}$ indoor Aquatic Research Facility (ARF) of Wageningen University, the Netherlands.

Table 1 Experimental design. Eight gas : liquid ratios (GLRs) were tested for their effect on carbon dioxide removal and heat loss from water passing a trickling filter (TF). TF dimensions were: height 2.5 $\mathrm{m}$, filter media height $1.80 \mathrm{~m}$, filter inner diameter $0.9 \mathrm{~m}$, cross sectional surface area $0.64 \mathrm{~m}^{2}$. The filter media used was BIO-NET® 200 (NSB GmbH, Nordenham, Germany). Airflow through the TF was controlled by a fan on top of the TF (top section TF was hermetically sealed).

\begin{tabular}{lccccccccc}
\hline & & \multicolumn{7}{c}{ G : L Ratio (GLR) } \\
\cline { 3 - 8 } Parameter & Unit & $\mathbf{1}$ & $\mathbf{2}$ & $\mathbf{3}$ & $\mathbf{5}$ & $\mathbf{7}$ & $\mathbf{1 0}$ & $\mathbf{1 2}$ \\
\hline Water flow & $\mathrm{m}^{3} / \mathrm{h}$ & 6 & 6 & 6 & 6 & 6 & 6 & 6 \\
Air flow & & $\mathrm{m}^{3} / \mathrm{h}$ & 6 & 12 & 18 & 30 & 42 & 60 & 72 \\
\hline
\end{tabular}

*the airflow through the trickling filter was a counter current flow and was maintained using forced air ventilation.

\subsection{The pilot scale recirculating aquaculture system}

The pilot scale RAS in this study (Fig. 1) was in operation for several years prior to the start of the experiment. The RAS comprises four rectangular fish tanks (water volume (V) $510 \mathrm{~L} / \mathrm{tank}$, surface area 
$0.75 \mathrm{~m}^{2}$, hydraulic retention time (HRT approx. $45 \mathrm{~min}$.) which were stocked with growing African catfish (Clarias gariepinus). Water was flowing by gravity from the fish tanks to a drum filter (Model HDF 501-1P, 0.75A, mesh-size screen $60 \mu \mathrm{m}, \mathrm{V}=50 \mathrm{~L}$ : Veolia Water technologies AB-Hydrotech, Vellinge, Sweden) for suspended solids removal (drum filter backwash water was taken from sump 1, backwash operation was intermittent). From the drum filter water flowed by gravity to sump 1 ( 1 x 0.9 $\mathrm{x} 0.9 \mathrm{~m}, \mathrm{~V}=688 \mathrm{~L}$, HRT $5 \mathrm{~min}$.) where it was collected and pumped (centrifugal pump, SPECK, Model BADU 40/13G-AK, 3.6 A, Zevenaar, The Netherlands) to the top of the trickling filter (full cone spiral spray nozzle, (Type $2 \mathrm{H}$ SPN 020, spray angle $120^{\circ}$; Enexio, Czech Republique); the height of the biofilter was $2.5 \mathrm{~m}$; height of the media $1.8 \mathrm{~m}$; inner biofilter diameter $0.9 \mathrm{~m}$; cross sectional surface area $0.64 \mathrm{~m}^{2}$; media volume $1.14 \mathrm{~m}^{3}$; filter media: Bionet (BIO-NET ${ }^{\circledR} 200$, specific surface area $(\mathrm{a})=$ $200 \mathrm{~m}^{2} / \mathrm{m}^{3}, 95 \%$ cavity percentage, standard block size L x W x H in cm: 50 x 50 x 60, weight $49 \mathrm{~kg} / \mathrm{m}^{3}$, NSB GmbH, Nordenham, Germany); hydraulic load $144 \mathrm{~m}^{3} /$ day; hydraulic surface load $226 \mathrm{~m}^{3} / \mathrm{m}^{2} . \mathrm{d}$; contact time between wastewater and air in TF was approximately $10 \mathrm{sec}$.). A ventilation fan (air tight housing, air flow range $6-70 \mathrm{~m}^{3} / \mathrm{h}$, Systemair RVK 100E2-A1, $2300 \mathrm{RPM}, 25 \mathrm{KW}$, Harderwijk, The Netherlands), mounted on top of the trickling filter, was creating a counter current flow through the filter. All water passing the trickling filter was collected in sump $2(\mathrm{~V}=330 \mathrm{~L}$, hydraulic retention time 3 min.) from where a pump (SPECK, Model BADU 40/13G-AK, 3.6 A) supplied the fish tanks with water $\left(2.4 \mathrm{~m}^{3} / \mathrm{h}, 0.6 \mathrm{~m}^{3} / \mathrm{h}\right.$ per fish tank). Excess water collected in sump 2 was flowing by gravity through the water overflow of sump 2 back into sump 1. Sump 1 was equipped with: (1) a pH controller (Endress-Hauser Liquisys M, Endress+Hauser, Burlington, Canada) sensing and controlling the $\mathrm{pH}$ at 7 by supplying sodium hydroxide $(\mathrm{NaOH}, 32 \%)$ to sump 1 (the hydraulic retention time in sump 1 was long enough to establish the acid-base equilibrium (Grace and Piedrahita, 1994)); (2) a make-up water supply line with water meter (Zinner, Kiwa, Rijswijk, The Netherlands) connected to a float valve for water level control in sump 1, (3) a heater and, (4) a water overflow for excess system water. The water treatment units of the pilot scale RAS were installed in the water treatment room (height $6 \mathrm{~m}$, width 10 $\mathrm{m}$, length $35 \mathrm{~m}$ ) of the Aquatic Research Facility (ARF) of Wageningen University. The water treatment room was equipped with an air conditioner (set point temperature in this room was $20^{\circ} \mathrm{C}$ ). 


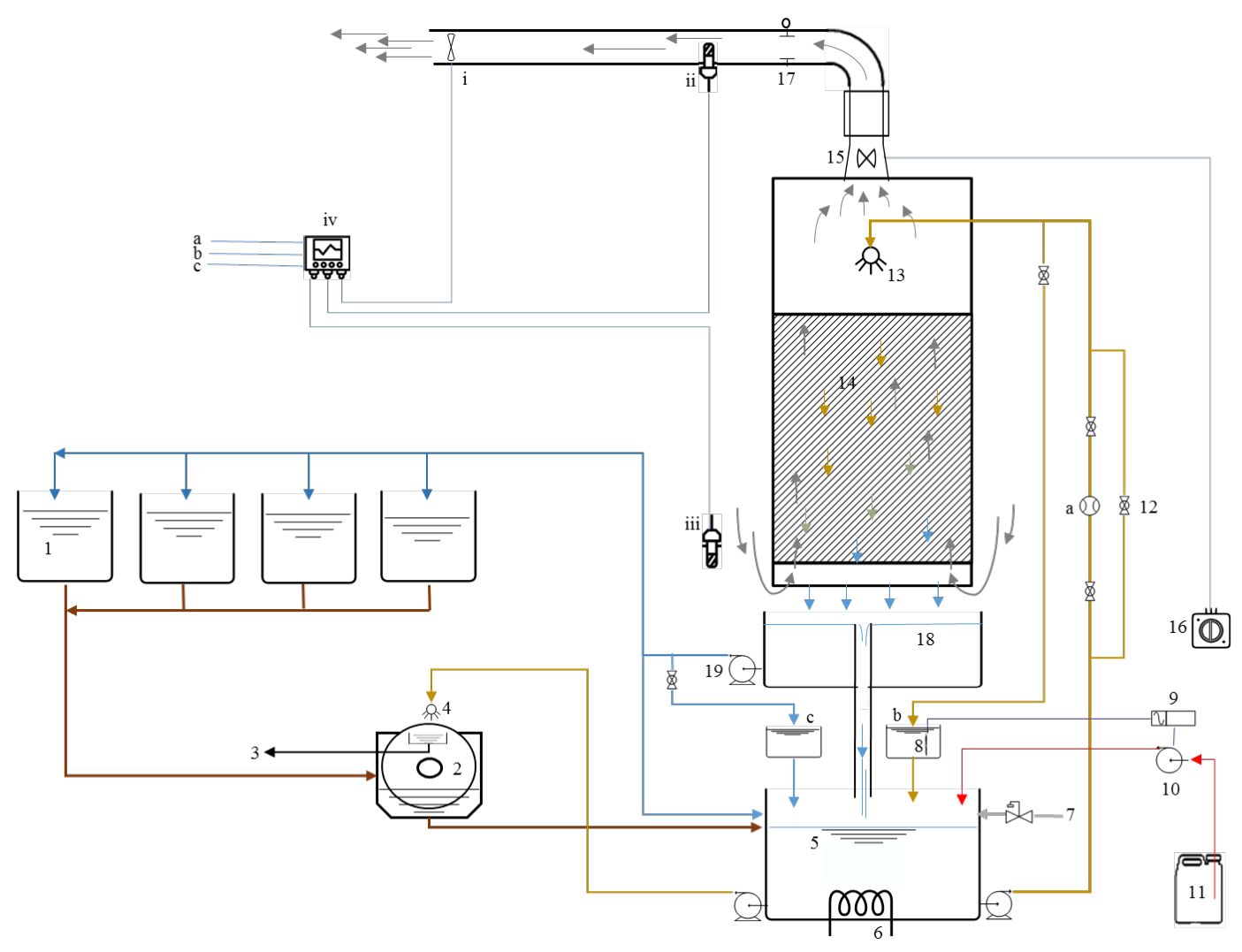

Fig. 1. Schematic configuration of the pilot scale RAS: (1) Fish tanks, (2) Drum filter, (3) Waste discharge, (4) Backwash water, (5) Sump 1, (6) Heater, (7) Make-up water supply line, (8) pH probe of $\mathrm{pH}$ Controller, (9) $\mathrm{pH}$ relay controller for $\mathrm{NaOH}$ dosing pump, (10) Peristaltic pump for $\mathrm{NaOH}$ dosing, (11) Sodium hydroxide (NaOH) reservoir, (12) Valve, (13) Full cone spiral spray nozzle, (14) Trickling filter, (15) Fan, (16) Potential meter controlling the speed of the fan, (17) Iris valve, (18) Sump 2 with water overflow to Sump 1, (19) Water supply fish tanks. Installed air sensor measurements: (i) Air flow meter (Anemometer), (ii) Infrared $\mathrm{CO}_{2}$-sensor and temperature and relative humidity sensor in the air outlet, (iii) Infrared $\mathrm{CO}_{2}$-sensor, temperature and relative humidity sensor and barometer (to measure the ambient pressure) in the air inlet, (iv) Data logger. Installed water sensor measurements: (a) Paddlewheel flow transmitter, $(b, c)$ Portable multimeter for continuous measurement of water temperature, oxygen, conductivity and $\mathrm{pH}$ sensor in the water inlet and outlet of the trickling filter. Water samples to determine TAN, $\mathrm{NO}_{2}-\mathrm{N}, \mathrm{NO}_{3}-\mathrm{N}$, total inorganic carbon (TIC) and alkalinity in the water inlet and outlet of the trickling filter were taken from location (b) and (c).

\subsection{Fish and feeding}

The fish were obtained from a commercial farm (Fleuren and Nooijen, Someren, The Netherlands) and were fed a fixed amount of feed per tank of a commercial diet (3.0 or $4.5 \mathrm{~mm}$ sinking pellet, Coppens Special Pro EF; Altech Coppens, Helmond, The Netherlands). Water temperature and $\mathrm{pH}$ were maintained at $27^{\circ} \mathrm{C}$ and $\mathrm{pH} 7$. Water quality in the fish tanks was kept within the allowable range/max. value set for African catfish: temperature $25-27^{\circ} \mathrm{C} ; \mathrm{pH} 6.5-8.0 ; \mathrm{O}_{2}$ concentration in the range of 3-8 $\mathrm{mg} / \mathrm{L} ; \mathrm{CO}_{2}<25 \mathrm{mg} / \mathrm{L}$ (Eding et al., 2006); $\mathrm{NH}_{3}-\mathrm{N}<0.34 \mathrm{mg} / \mathrm{L}$ (Schram et al., 2010); $\mathrm{NO}_{2}-\mathrm{N}<0.6$ 
$\mathrm{mg} / \mathrm{L}$ (Roques et al., 2015); $\mathrm{NO}_{3}-\mathrm{N}<140 \mathrm{mg} / \mathrm{L}$ (Schram et al., 2014). The RAS make up water supply was set at $700 \mathrm{~L} / \mathrm{d}$. Cumulative feed burden (CFB)(Colt et al., 2006) was approximately $4300 \mathrm{mg}$ feed/L.

\subsection{Sampling and analysis}

Sampling. Water samples $(2 \times 10 \mathrm{ml}$ tubes with stoppers, completely filled without air) were taken on the two days each GLR was tested to determine TAN, $\mathrm{NO}_{2}-\mathrm{N}, \mathrm{NO}_{3}-\mathrm{N}$, total inorganic carbon (TIC) and alkalinity in the influent and effluent of the trickling filter (for sampling locations see Fig. 1). All water samples per GLR tested were taken at 08:00, 11:00, 14:00, 17:00, 20:00 and 23:00 for 2 subsequent days, stored on ice or in the refrigerator $\left(\right.$ at $\left.4{ }^{\circ} \mathrm{C}\right)$ and were analysed within 12 hours after the last sample was taken.

Analysis. Water samples were analysed using an AutoAnalyser $\left(\mathrm{San}^{++}\right.$autoanalyzer, Skalar, Breda, The Netherlands) for concentration of TAN (TAN= $\mathrm{NH}_{3}-\mathrm{N}+\mathrm{NH}_{4}{ }^{+}-\mathrm{N}$ ), (Skalar protocol number 155-006); nitrite-N $\left(\mathrm{NO}_{2}-\mathrm{N}\right)$, (Skalar protocol number 467-033), nitrate-N $\left(\mathrm{NO}_{3}-\mathrm{N}\right)$, (Skalar protocol number 461318 ) and Total Inorganic Carbon (Skalar protocol number 185-312; TIC was measured as mg CO2/L; accuracy and precision was approximately $1 \%$ and $2 \%$ respectively for the $40 \mathrm{mg} \mathrm{CO} 2 / \mathrm{L}$ standard which was in the middle of our measurement range (see Table 6). To evaluate the quality of TIC measurements by the Skalar auto-analyzer water samples were send to an external lab (CBLB, WUR, Wageningen the Netherlands) for total carbon (TC) and TIC measurements using a Shimadzu 5050A TOC analyzer (Shimadzu Benelux, The Netherlands) and a similar Skalar SAN++ autoanalyzer (Skalar Analytical B.V., The Netherlands). Results showed that our Skalar TIC measurements were on average $3 \%$ lower when compared with the Shimadzu analysis and on average 1\% higher when compared with the measurements by a similar Skalar autoanalyzer as ours. Alkalinity (in meq /L) was measured by titration directly after sampling (Radio Titrator model TIM840 Potentiometric Titration Manager monoburette, Radiometer analytical, HACH, US). In this study total alkalinity (TAlk) measurements were only used to characterise the water quality and were not used to calculate the TIC or $\mathrm{CO}_{2}$ concentration. The presence of non-carbonate alkalinity (NC-Alk) due to the accumulation of orthophosphorus (ortho-phosphorus concentration in our study $12 \pm 2 \mathrm{mg} \mathrm{PO} 4-\mathrm{P} / \mathrm{L}$ ) and humic acids (Abril et al., 2015; Colt and Maynard, 2019a, b) leaching from digested/degraded plant material in the faecal waste of fish in our low water exchange RAS (cumulative feed burden $(4300 \mathrm{mg} / \mathrm{L}$ ) might result in an overestimation of the TIC and $\mathrm{CO}_{2}$ concentration when using the reported ALk and $\mathrm{pH}$.

\subsection{Sensor measurements.}

Air measurements. The airflow ( $\left.\mathrm{m}^{3} / \mathrm{day}\right)$ across the trickling was measured at the end of the air outflow ventilating shaft of the trickling filter using a Vane Anemometer (Lambrecht meteo-Model 1468, GmBH Gottingen, Germany) (Fig. 1). Carbon dioxide was measured by two $\mathrm{CO}_{2}$-probes $\left(\mathrm{CO}_{2}\right.$-probe characteristics: 0-10,000 ppm, infra-red light source; automatic compensation for temperature, pressure; heating to avoid condensation on optical elements, IP65 classified housing, accuracy (including repeatability and non-linearity) at $25^{\circ} \mathrm{C}$ and $1013 \mathrm{hPa}$ for $0-3000 \mathrm{ppm} \mathrm{CO} \mathrm{CO}_{2}$ is $\pm 40 \mathrm{ppm} \mathrm{CO}, \mathrm{CO}_{2}$-probe GMP252, Vaisala, Helsinki, Finland), which were calibrated by the company in the range of 0-3000 ppm $\mathrm{CO}_{2}$ (our measurements were in the range 457-1967 ppm, see Table 5), and by them installed in the ingoing and outgoing air of the trickling filter (Fig. 1). Temperature and relative humidity $(0-100 \%$ $\mathrm{RH}$ ) in the inlet and outlet air were measured concomitantly using two temperature and relative humidity probes (temperature \& relative humidity probe HMT 337, a warmed probe for high performance in condensing environments, Vaisala, Helsinki, Finland). Accurate barometric pressure measurement (in $\mathrm{hPa}$ ) of the ambient environment was done using the Barometer PTB110, range 500-1100 hPa 
(Vaisala, Helsinki, Finland). The GLR (range 1.2 to 15.7) in this study was adjusted by a speed control potential meter (Systemair 5000, Type RE 1.5, IP 54, Max 1.5 A, Sweden) connected to the ventilation fan and an iris valve (SPI 100, Systemair Sverige AB, Skinnskaateberg, Sweden) in the downstream flow (Fig. 1).

Water measurements. Water temperature $\left({ }^{\circ} \mathrm{C}\right)$, oxygen concentration $(\mathrm{mg} / \mathrm{L})$, conductivity $(\mu \mathrm{S} / \mathrm{cm})$ and $\mathrm{pH}$ were measured in the water influent and effluent of the trickling filter using two portable multimeters (Multi 3340i, WTW, Weilheim, Germany). During the experimental period off-set between the two water and air measurement locations (Fig.1) was checked for the $\mathrm{pH}, \mathrm{O}_{2}$, conductivity and $\mathrm{CO}_{2}$ gas meter, by placing them in the same measurement location (in inlet or out let location). When off-sets between the input and outlet probes were observed they were calibrated. The water flow was measured in the water inlet of the trickling filter using the paddlewheel flow transmitter F6.30.01 (Aliaxis Utilities \& Industries, Spanga, Sweden). Make up water supply was measured by reading the water meter (Zinner, Kiwa, Rijswijk, The Netherlands) in every sampling period.

Sensor management and data collection. One week prior to the start of the experiment all measuring equipment was set up and calibrated for the experimental work. All $\mathrm{pH}$ probes were cleaned daily and two-point calibrated weekly (pH 4.01 and $\mathrm{pH} 7.00$ technical buffer solution, WTW, Weilheim, Germany) a few hours before starting to $\log$ the $\mathrm{pH}$ measurement data on the measuring days. $\mathrm{pH}$ measurements were on-line measurements to prevent effects of temperature change, $\mathrm{CO}_{2}$ degassing and microbial respiration in grab samples. Air (air outflow rate; carbon dioxide; temperature and relative humidity; differential pressure and barometric pressure) and water (temperature, oxygen, electrical conductivity, $\mathrm{pH}$, carbon dioxide and water flow rate) sensor measurements were logged every 5 minutes to determine the effect of GLRs on $\mathrm{CO}_{2}$ removal from the water. The location where sensors were installed in the pilot scale RAS are presented in Figure 1. The air quality sensors and water flow meter ( $\max$ flow $=10 \mathrm{~m}^{3} / \mathrm{h}$ ) were connected with a data logger (DT 85, V. 9.20, DataTaker, Thermo Fisher Scientific Australia Pty Ltd, Scoresby, Australia). Data were collected by continuous measurements during each tested GLR in every week. The average of every 3 hours continuous data from the 2 last days of every measuring week from 08:00 AM to 11:00 PM was used for analysis of data.

\subsection{Calculations}

The main calculations for fish performance, $\mathrm{TF} \mathrm{CO}_{2}$-degassing performance and heat loss across the TF are presented in table 2. To calculate heat loss across the TF a simple thermodynamic model for calculating the energy loss in the trickling filter, based on Mollier functions (ASHRAE, 2009), was constructed in MATLAB R2016b (Mathworks Inc., Natick, MA, USA). The enthalpy and the density of the air were calculated by the Mollier function for the measured temperature and humidity. The total latent heat loss is calculated as the difference between ingoing/outgoing water vapour concentration by Mollier function. In our calculations, we assumed the heat gains and losses on the side walls of the trickling filter were negligible. All calculations with the thermodynamic model were conducted using a 3 hours time interval the same as the sampling and measuring time interval in this study. 
Table 2 Calculations.

\begin{tabular}{|c|c|c|}
\hline Parameter & Unit & Formula \\
\hline \multicolumn{3}{|l|}{ Fish performance } \\
\hline Initial individual fish weight $\left(\mathrm{W}_{\mathrm{i}}\right)$ & g & $=\mathrm{W}_{\mathrm{tot}, \mathrm{i}} / \mathrm{n}_{\mathrm{i}}$ \\
\hline Final individual fish weight $\left(\mathrm{W}_{\mathrm{f}}\right)$ & $\mathrm{g}$ & $=\mathrm{W}_{\mathrm{tot}, \mathrm{f}} / \mathrm{n}_{\mathrm{f}}$ \\
\hline Geometric mean body weight $\left(\mathrm{W}_{\mathrm{g}}\right)$ & $\mathrm{g}$ & $=\mathrm{e}^{\left(\left(\operatorname{Ln}(\mathrm{Wf})+\operatorname{Ln}\left(\mathrm{Wi}_{\mathrm{i}}\right) / 2\right)\right.}$ \\
\hline Relative feeding rate (FR) & $\% \mathrm{~W}_{\mathrm{g}} / \mathrm{d}$ & $=\left(\left(\mathrm{FC} /\left(\left(\mathrm{n}_{\mathrm{i}}+\mathrm{n}_{\mathrm{f}}\right) / 2\right)\right) / \mathrm{t} / \mathrm{W}_{\mathrm{g}} * 100 \%\right.$ \\
\hline Specific growth rate (SGR) & $\% \mathrm{~W}_{\mathrm{g}} / \mathrm{d}$ & $=\left(\left(\operatorname{Ln}\left(\mathrm{W}_{\mathrm{f}}\right)-\mathrm{Ln}\left(\mathrm{W}_{\mathrm{i}}\right)\right) / \mathrm{t}\right)^{*} 100 \%$ \\
\hline Feed conversion ratio (FCR) & $\mathrm{g}$ feed/g growth & $=\left(\mathrm{FC} /\left(\left(\mathrm{n}_{\mathrm{i}}+\mathrm{n}_{\mathrm{f}}\right) / 2\right)\right) /\left(\mathrm{W}_{\mathrm{f}}-\mathrm{W}_{\mathrm{i}}\right)$ \\
\hline $\begin{array}{l}\text { Trickling filter } \mathrm{CO}_{2} \text {-degassing performance } \\
\Delta \mathrm{CO}_{2}(\mathrm{~g})\end{array}$ & ppm & $=\mathrm{CO}_{2, \text { out }}(\mathrm{g})-\mathrm{CO}_{2, \mathrm{in}}(\mathrm{g})$ \\
\hline Relative $\mathrm{CO}_{2}(\mathrm{~g})$ uptake & $\%$ & $=\left(\left(\mathrm{CO}_{2, \text { out }}(\mathrm{g})-\mathrm{CO}_{2, \mathrm{in}}(\mathrm{g})\right) / \mathrm{CO}_{2, \mathrm{in}}(\mathrm{g})\right)^{*} 100$ \\
\hline$\Delta \mathrm{CO}_{2}(\mathrm{aq})$ & $\mathrm{mg} / \mathrm{L}$ & $\left.=\left(\left(\Delta \mathrm{CO}_{2}(\mathrm{~g}, \mathrm{ppm}) * 44 \mathrm{mg}\right) / 24.45 * 1000 \mathrm{~L}\right) * \mathrm{GLR}\right)$ \\
\hline $\mathrm{CO}_{2}(\mathrm{~g})$ uptake per hour & $\mathrm{gCO}_{2} / \mathrm{h}$ & $=\Delta \mathrm{CO} 2(\mathrm{aq})\left(\mathrm{mg} / \mathrm{L} \sim \mathrm{g} / \mathrm{m}^{3}\right)^{*} \mathrm{Q}_{\text {water }}$ \\
\hline Total inorganic carbon $[\mathrm{TIC}]^{\mathrm{a}}$ & $\mathrm{mol} / \mathrm{L}$ & $=(\mathrm{TIC}$ as $\mathrm{mg} \mathrm{CO} / \mathrm{L})) /\left(44000 \mathrm{mg} / \mathrm{mol} \mathrm{CO}_{2}\right)$ \\
\hline Dissolved $\mathrm{CO}_{2}(\mathrm{aq})\left[\mathrm{H}_{2} \mathrm{CO}_{3} *\right]^{\mathbf{b}}$ & $\mathrm{mol} / \mathrm{L}$ & $=[\mathrm{TIC}] /\left(1+\mathrm{K}_{0} \mathrm{~K}_{1} /\left[\mathrm{H}^{+}\right]+\mathrm{K}_{0} \mathrm{~K}_{1} \mathrm{~K}_{2} /\left[\mathrm{H}^{+}\right]^{2}\right)$ \\
\hline Total inorganic carbon [TIC] & $\mathrm{mol} / \mathrm{L}$ & $=\left[\mathrm{H}_{2} \mathrm{CO}_{3}^{*}\right]+\left[\mathrm{HCO}_{3}^{-}\right]+\left[\mathrm{CO}_{3}^{2-}\right]$ \\
\hline Dissolved $\mathrm{CO}_{2}$ in or out $(\mathrm{aq})$ & $\mathrm{mg} / \mathrm{L}$ & $=$ Dissolved $\mathrm{CO}_{2}(\mathrm{aq}) * 44000 \mathrm{mg} \mathrm{CO} / \mathrm{mol}$ \\
\hline Relative $\mathrm{CO}_{2}(\mathrm{aq})$ removal & $\%$ & $=\left(\left(\mathrm{CO}_{2 \text { in }}(\mathrm{aq})-\mathrm{CO}_{2 \text { out }}(\mathrm{aq})\right) / \mathrm{CO}_{2 \text { in }}(\mathrm{aq})\right)^{*} 100$ \\
\hline \multicolumn{3}{|l|}{ Heat loss across the trickling filter } \\
\hline Total energy in vented inlet air $\left(\text { Energy }_{\text {air inlet }}\right)^{c}$ & $\mathrm{~kJ} / \mathrm{h}$ & $=$ Enthalpy ${ }_{\text {air }} * \rho_{\text {air }} * Q_{\text {air }}$ \\
\hline Total energy in vented outlet air (Energy air outlet $)^{\mathrm{c}}$ & $\mathrm{kJ} / \mathrm{h}$ & $=$ Enthalpy ${ }_{\text {air }} * \rho_{\text {air }} * Q_{\text {air }}$ \\
\hline Total heat loss & $\mathrm{kJ} / \mathrm{h}$ & $=$ Energy $_{\text {air outlet }}-$ Energy $_{\text {air inlet }}$ \\
\hline Evaporation rate $\left(\mathrm{M}_{\text {evap }}\right)$ & $\mathrm{g} / \mathrm{h}$ & $=\left(\mathrm{C}_{\text {out }} * \mathrm{Q}_{\text {air }}-\mathrm{C}_{\text {in }} * \mathrm{Q}_{\text {air }} *\left(\mathrm{~T}_{\text {air }, \text { in }}+273.15\right) /\left(\mathrm{T}_{\text {air }, \text { out }}+273.15\right)\right)$ \\
\hline Water content air $\left(\mathrm{C}_{\text {in or out }}\right)$ & $\mathrm{g} / \mathrm{m}^{3}$ & $=\left(1000 * \mathrm{P}^{*} 0.018 / 8.314\right) /\left(\mathrm{T}_{\text {air }}\right.$, in or out +273.15$)$ \\
\hline Evaporation per $\mathrm{m}^{3}$ air ( $\left.\mathrm{M}_{\text {evap_air }}\right)$ & $\mathrm{g} / \mathrm{m}^{3}$ & $=\mathrm{M}_{\text {evap_air }} / \mathrm{Q}_{\text {air }}$ \\
\hline Sensible heat loss & $\mathrm{kJ} / \mathrm{h}$ & $=$ Total heat loss - Latent heat loss \\
\hline Latent heat loss $\left(\mathrm{Q}_{\text {Latent }}\right)^{\mathrm{c}}$ & $\mathrm{kJ} / \mathrm{h}$ & $=\mathrm{M}_{\text {evap }} *\left(2501-2.42 * \mathrm{~T}_{\text {air,out }}\right)$ \\
\hline Heat loss airflow & $\mathrm{kJ} / \mathrm{m}^{3}$ & $=$ Total heat loss $/ \mathrm{Q}_{\text {air }}$ \\
\hline Heat loss per $\mathrm{CO}_{2}$ uptake air & $\mathrm{kJ} / \mathrm{g} \mathrm{CO}_{2}$ & $=$ Total heat loss $/ \mathrm{CO}_{2}(\mathrm{~g})$ uptake per hour \\
\hline Heat loss per kg feed & $\mathrm{MJ} / \mathrm{kg}$ feed & $=($ Total heat loss $/ 1000) * 24 \mathrm{~h}) / 3 \mathrm{~kg}$ feed \\
\hline
\end{tabular}

${ }^{a}$ TIC was calculated from total inorganic carbonate measured as $\mathrm{CO}_{2}(\mathrm{mg} / \mathrm{L})$ using the Skalar autoanalyzer (see section 2.5); ${ }^{\mathrm{b}}$ Total dissolved $\mathrm{CO}_{2}\left[\mathrm{H}_{2} \mathrm{CO}_{3}{ }^{*}\right]$ was calculated according to (Summerfelt et al., 2000) using $K_{0}=1.58^{*} 10^{-3}, K_{I}=2.83^{*} 10^{-4}, K_{2}=4.68^{*} 10^{-11}$; ${ }^{\mathrm{c}}$ Calculated using a simple thermodynamic model for calculating the energy loss in the trickling filter, based on Mollier functions (ASHRAE, 2009), was constructed in MATLAB R2016b (Mathworks Inc., Natick, MA, USA). $\mathrm{W}_{\mathrm{tot}}=$ total biomass (in g) per tank; i: initial; f: final; FC: total feed intake (g feed/tank), n: number of fish per tank; GLR= gas liquid ratio; $Q_{\text {air }}$ : the vented air through the trickling filter $\left(\mathrm{m}^{3} / \mathrm{h}\right)$; Enthalpy air $=$ heat content of air $(\mathrm{kJ} / \mathrm{kg}) ; \rho_{\text {air }}$ is density of air $\left(\mathrm{kg} / \mathrm{m}^{3}\right) ; \mathrm{C}_{\text {in or out }}$ is the water content in ingoing or outgoing air $\left(\mathrm{kg} / \mathrm{m}^{3}\right) ; \mathrm{T}_{\text {in or out }}$ is the ingoing or outgoing air temperature $\left({ }^{\circ} \mathrm{C}\right) ; \mathrm{P}$ is water vapour pressure $(\mathrm{kPa}) ; \mathrm{M}_{\text {evap }}=$ mass of evaporated water $(\mathrm{kg} / \mathrm{h}) ;\left(2501-2.42 * T_{\text {air }}\right)$ is enthalphy of vapour air for the given temperature ( $\mathrm{kJ} / \mathrm{kg}$ ) (ASHRAE, 2009); $\mathrm{CO}_{2}(\mathrm{~g})$ uptake: absolute $\mathrm{CO}_{2}$ uptake by air $\left(\mathrm{gCO}_{2} / \mathrm{h}\right)$.

\subsection{Statistical analysis}

Analysis of covariance (ANCOVA) was performed to assess the effect of independent variables on the dependent variable $\left(\mathrm{CO}_{2}\right.$ removal from the gas and liquid phase). It was used to reduce the number of air and water quality parameters into a smaller and more manageable number of variables that account better for the underlying variance (causal impact) in the measured phenomenon. Outliers of the dependent variables were deleted when higher values than three times the interquartile range were observed. Normality of residuals and homogeneity of variance of the data was verified using the Shapiro-Wilk test and the Levene's test, assuming equal variances $(n=6)$, respectively $(p>0.05)$. The 
$\mathrm{CO}_{2}(\mathrm{~g})$ removal data of GLR 7.1:1 was not normally distributed. The other tests of normality showed a normal distribution for all dependent variables as function of GLR $(p>0.05)$. Due to the low number of samples, normality for the GLR of 7.1:1 is still assumed. Data on $\mathrm{CO}_{2}$ removal from water and air did not comply with the criteria of homogeneity of variance (Levene's test). Therefore, these data were analyzed using a one-way ANOVA followed by post hoc comparison of groups of data using the GamesHowell test (unequal variances assumed) at the significance level of 0.05 . Linear regression analysis was performed to conceptualize an equation for energy loss across the trickling filter. All statistical analyses were performed using IBM SPSS statistics, version 24 (IBM Corp., Armonk, USA). All data in tables are presented as mean \pm standard deviation of 3-hourly data.

\section{Results}

In this chapter first water quality data are presented to assess whether these experimental conditions might have affected the $\mathrm{CO}_{2}$ removal and energy loss from water through the trickling filter. Secondly, the results of the effect of GLR on $\mathrm{CO}_{2}$ removal from the water based on measurements in the air and in the water are presented and finally results on energy loss due to the applied GLR are reported.

\subsection{Experimental conditions}

In table 3 the measured data of the water quality parameters are reported (means \pm SD) for each GLR. All measured water quality parameters were in the allowable range (see par. 2.3) for African catfish and TF's biofilm. Mean TF inlet temperatures varied between 27.0 and $27.5^{\circ} \mathrm{C}$ for the different GLRs. Mean oxygen values were between 6.4 and $6.7 \mathrm{mg} / \mathrm{L}$ and the mean inlet $\mathrm{pH}$ varied between 7.02-7.12. Mean conductivity varied between 1110 to $1464 \mu \mathrm{S} / \mathrm{cm}$ (conductivity of the make-up water supply was about $200 \mu \mathrm{S} / \mathrm{cm}$ at $14^{\circ} \mathrm{C}$ ). Mean TAN, $\mathrm{NO}_{2}{ }^{-}-\mathrm{N}$ and $\mathrm{NO}_{3}{ }^{-}-\mathrm{N}$ concentrations ranged between $0.49-0.61 \mathrm{mg} / \mathrm{L}$, $0.24-0.31 \mathrm{mg} / \mathrm{L}$ and $103-146 \mathrm{mg} / \mathrm{L}$, respectively. The daily make up water supply ranged between $0.34-$ $0.82 \mathrm{~m}^{3} /$ day . The daily measured $\mathrm{EC}, \mathrm{TAN}$ and $\mathrm{NO}_{2}{ }^{-}-\mathrm{N}$ values were relatively constant within and between the different tested GLRs. Analysis of covariance showed there was no significant effect of inlet temperature, oxygen, conductivity, $\mathrm{pH}, \mathrm{TAN}$, nitrite- $\mathrm{N}$, nitrate-N and make up water on carbon dioxide removal from water indicating GLR in this experiment was the single factor effecting $\mathrm{CO}_{2}$ removal.

Fish performance data over the entire experimental period are given in table 4. During the 118 days experimental period the overall survival percentage of the fish was $99 \%$. The mean daily feed load was approximately $3.0 \mathrm{~kg} / \mathrm{d}$ as total of the 4 tanks. Realised feeding levels and FCRs per tank were 0.33 $1.69 \% \mathrm{BW} / \mathrm{d}$ and $0.9-1.9$ respectively for an average geometric mean bodyweight per tank of $673-$ $3038 \mathrm{~g}$. The initial and final total biomass in the 4 tanks was 293.1 and $590.6 \mathrm{~kg}$, respectively.

Table 3 Water quality parameters per GLR measured in the inlet water of the trickling filter. Values are mean $\pm \mathrm{SD}(\mathrm{n}=12)$.

\begin{tabular}{|c|c|c|c|c|c|c|c|c|c|}
\hline \multirow[b]{2}{*}{ Water quality parameters } & \multirow[b]{2}{*}{ Unit } & \multicolumn{8}{|c|}{ G : L ratio (GLR) } \\
\hline & & $1.2: 1$ & 2.3 & $3.2: 1$ & 5.0:1 & $7.1: 1$ & $9.2: 1$ & 11.7:1 & $15.7: 1$ \\
\hline Temperature & ${ }^{\circ} \mathrm{C}$ & $27.2 \pm 0.4$ & $27.3 \pm 0.2$ & $27.0 \pm 0.1$ & $27.3 \pm 0.2$ & $27.4 \pm 0.4$ & $27.3 \pm 0.3$ & $27.4 \pm 0.3$ & $27.5 \pm 0.3$ \\
\hline Oxygen & $\mathrm{mg} / \mathrm{L}$ & $6.62 \pm 0.1$ & $6.36 \pm 0.1$ & $6.68 \pm 0.1$ & $6.44 \pm 0.1$ & $6.64 \pm 0.1$ & $6.71 \pm 0.1$ & $6.47 \pm 0.2$ & $6.56 \pm 0.1$ \\
\hline Conductivity & $\mu \mathrm{S} / \mathrm{cm}$ & $1110 \pm 26$ & $1452 \pm 58$ & $1303 \pm 14$ & $1464 \pm 117$ & $1457 \pm 54$ & $1343 \pm 12$ & $1406 \pm 8$ & $1408 \pm 11$ \\
\hline $\mathrm{pH}$ & & $7.12 \pm 0.1$ & $7.02 \pm 0.1$ & $7.05 \pm 0.1$ & $7.02 \pm 0.1$ & $7.07 \pm 0.1$ & $7.05 \pm 0.1$ & $7.04 \pm 0.1$ & $7.06 \pm 0.1$ \\
\hline TAN $^{*}$ & $\mathrm{mg} / \mathrm{L}$ & $0.55 \pm 0.1$ & $0.61 \pm 0.1$ & $0.59 \pm 0.1$ & $0.49 \pm 0.1$ & $0.61 \pm 0.1$ & $0.52 \pm 0.1$ & $0.60 \pm 0.1$ & $0.57 \pm 0.0$ \\
\hline$\triangle \mathrm{TAN}$ & $\mathrm{mg} / \mathrm{L}$ & $0.37 \pm 0.0$ & $0.39 \pm 0.1$ & $0.36 \pm 0.1$ & $0.38 \pm 0.0$ & $0.53 \pm 0.0$ & $0.40 \pm 0.1$ & $0.35 \pm 0.1$ & $0.45 \pm 0.0$ \\
\hline $\mathrm{NO}_{2}-\mathrm{N}$ & $\mathrm{mg} / \mathrm{L}$ & $0.26 \pm 0.0$ & $0.30 \pm 0.0$ & $0.27 \pm 0.0$ & $0.29 \pm 0.0$ & $0.28 \pm 0.0$ & $0.29 \pm 0.0$ & $0.24 \pm 00$ & $0.31 \pm 0.0$ \\
\hline $\mathrm{NO}_{3}-\mathrm{N}$ & $\mathrm{mg} / \mathrm{L}$ & $103.3 \pm 2.0$ & $146.0 \pm 5.3$ & $122.4 \pm 3.3$ & $133.7 \pm 6.2$ & $133.3 \pm 2.1$ & $129.8 \pm 2.9$ & $122.9 \pm 3.8$ & $129.3 \pm 4.8$ \\
\hline Make-up water & $\mathrm{m}^{3} / \mathrm{d}$ & $0.82 \pm 0.2$ & $0.57 \pm 0.0$ & $0.57 \pm 0.1$ & $0.34 \pm 0.0$ & $0.66 \pm 0.0$ & $0.65 \pm 0.0$ & $0.67 \pm 0.1$ & $0.70 \pm 0.0$ \\
\hline
\end{tabular}


Table 4 Fish performance during the 118 days experimental period.

\begin{tabular}{|c|c|c|c|c|c|}
\hline Biomass parameters & Unit & Tank 1 & Tank 2 & Tank 3 & Tank 4 \\
\hline Initial Biomass & g & 126063 & 127602 & 19921 & 19472 \\
\hline Initial number of fish & $\mathrm{n}$ & 46 & 71 & 74 & 74 \\
\hline Final Biomass & g & 154961 & 183681 & 126335 & 125611 \\
\hline Total feed supply & $\mathrm{g}$ & 54164 & 92393 & 99138 & 97788 \\
\hline Survival & $\%$ & 100 & 100 & 97.3 & 98.6 \\
\hline $\mathrm{BW}_{\mathrm{g}}$ & g & 3038.4 & 2156.3 & 687.3 & 672.9 \\
\hline Relative feeding rate & $\% \mathrm{BW} / \mathrm{d}$ & 0.33 & 0.51 & 1.70 & 1.69 \\
\hline SGR & $\% \mathrm{BW} / \mathrm{d}$ & 0.18 & 0.31 & 1.57 & 1.58 \\
\hline FCR & g feed/g growth & 1.87 & 1.65 & 0.93 & 0.92 \\
\hline
\end{tabular}

\subsection{Carbon dioxide removal from water, based on air measurements}

Results on $\mathrm{CO}_{2}$ removal from the water by air at different GLRs are presented in Table 5. For the tested GLRs mean water flow varied between $6.2-6.9 \mathrm{~m}^{3} / \mathrm{h}$; mean airflow between $6.6-99.2 \mathrm{~m}^{3} / \mathrm{h}$, and mean inlet and outlet $\mathrm{CO}_{2}(\mathrm{~g})$ concentration between $457-515 \mathrm{ppm}$ and 704-1967 ppm respectively. For the calculated $\Delta \mathrm{CO}_{2}$ (aq) removal (based on $\Delta \mathrm{CO}_{2}(\mathrm{~g})$ ) there was a significant increase in $\Delta \mathrm{CO}_{2}$ (aq) with increasing GLR $(1.2 ; 2.3 ; 3.2$; and $5.0(\mathrm{P}<0.05))$ and no difference between the GLRs 5.0; 7.1; 9.2 and 15.7. The highest numerically observed $\Delta \mathrm{CO}_{2}(\mathrm{aq})$ was for a GLR of 11.7. However, this $\mathrm{CO}_{2}(\mathrm{aq})$ removal was not significantly different from the removal at an GLR 7.1 and 15.7. The results show for increasing GLRs an asymptotical increase in the removal of $\mathrm{CO}_{2}$ from water (Fig. 2). The $\mathrm{CO}_{2}$ (aq) removal resulted in a mean $\mathrm{CO}_{2}(\mathrm{~g})$ increase from inlet to outlet air of $299-46 \%$ for the tested GLRs (1.215.7) and resulted in a $\mathrm{CO}_{2}(\mathrm{~g})$ uptake of $19-43 \mathrm{~g} / \mathrm{h}$ (Table 5).

Table 5 Effect of gas : liquid ratio (GLR) on $\mathrm{CO}_{2}$ removal from the water by measurements in the inlet and outlet air of the trickling filter. Values are mean $\pm \operatorname{SD}(n=12)$.

\begin{tabular}{|c|c|c|c|c|c|c|c|c|c|}
\hline \multirow[b]{2}{*}{ Parameter } & \multirow[b]{2}{*}{ Unit } & \multicolumn{8}{|c|}{ G : L ratio (GLR) } \\
\hline & & $1.2: 1$ & $2.3: 1$ & $3.2: 1$ & $5.0: 1$ & $7.1: 1$ & 9.2:1 & 11.7:1 & 15.7:1 \\
\hline Water flow & $\mathrm{m}^{3} / \mathrm{h}$ & $6.2 \pm 0.1$ & $6.4 \pm 0.0$ & $6.5 \pm 0.1$ & $6.4 \pm 0.0$ & $6.6 \pm 0.0$ & $6.9 \pm 0.1$ & $6.2 \pm 0.1$ & $6.3 \pm 0.0$ \\
\hline Air flow & $\mathrm{m}^{3} / \mathrm{h}$ & $6.6 \pm 2.2$ & $14.8 \pm 0.3$ & $20.5 \pm 0.2$ & $31.5 \pm 0.3$ & $46.7 \pm 0.3$ & $63.7 \pm 1.3$ & $73.3 \pm 1.6$ & $99.2 \pm 0.2$ \\
\hline Inlet $\mathrm{CO}_{2}(\mathrm{~g})$ & ppm & $493 \pm 16$ & $477 \pm 8$ & $515 \pm 37$ & $457 \pm 9$ & $470 \pm 15$ & $493 \pm 29$ & $457 \pm 10$ & $486 \pm 50$ \\
\hline Outlet $\mathrm{CO}_{2}(\mathrm{~g})$ & ppm & $1967 \pm 109$ & $1395 \pm 47$ & $1414 \pm 91$ & $1116 \pm 52$ & $981 \pm 39$ & $852 \pm 42$ & $774 \pm 23$ & $704 \pm 44$ \\
\hline$\Delta \mathrm{CO}_{2}(\mathrm{~g})$ & $\mathrm{ppm}$ & $1475 \pm 106$ & $918 \pm 45$ & $899 \pm 75$ & $659 \pm 53$ & $511 \pm 35.7$ & $359 \pm 29$ & $318 \pm 25$ & $219 \pm 24$ \\
\hline $\begin{array}{l}\Delta \mathrm{CO}_{2}(\mathrm{aq})^{*} \\
(\operatorname{method} 1)\end{array}$ & $\begin{array}{l}\mathrm{mg} / \mathrm{L} \text { uptake } \\
\text { from water }\end{array}$ & $3.1 \pm 0.4^{\mathrm{a}}$ & $3.9 \pm 0.2^{b}$ & $5.1 \pm 0.4^{\mathrm{c}}$ & $5.9 \pm 0.5^{\mathrm{d}}$ & $6.5 \pm 0.5^{\mathrm{d}, \mathrm{e}}$ & $6.1 \pm 0.5^{\mathrm{d}}$ & $6.7 \pm 0.3^{\mathrm{e}}$ & $6.1 \pm 0.8^{\mathrm{d}, \mathrm{e}}$ \\
\hline $\begin{array}{l}\text { Relative } \mathrm{CO}_{2}(\mathrm{~g}) \\
\text { uptake }\end{array}$ & $\%$ & $299 \pm 22$ & $192 \pm 10$ & $175 \pm 17$ & $144 \pm 12$ & $109 \pm 8$ & $73 \pm 7$ & $70 \pm 6$ & $46 \pm 7$ \\
\hline $\begin{array}{l}\mathrm{CO}_{2}(\mathrm{~g}) \text { uptake } \\
\text { per hour }\end{array}$ & $\mathrm{gCO}_{2} / \mathrm{h}$ & $19.2 \pm 2.6$ & $24.4 \pm 0.9$ & $33.2 \pm 2.8$ & $37.3 \pm 3.2$ & $42.9 \pm 3.0$ & $41.2 \pm 2.8$ & $41.9 \pm 2.9$ & $39.1 \pm 4.3$ \\
\hline
\end{tabular}

Means with different superscript letters indicate significant differences $(\mathrm{p}<0.05)$ in the post hoc Games-Howell test. * For the calculation see Table 2 . 


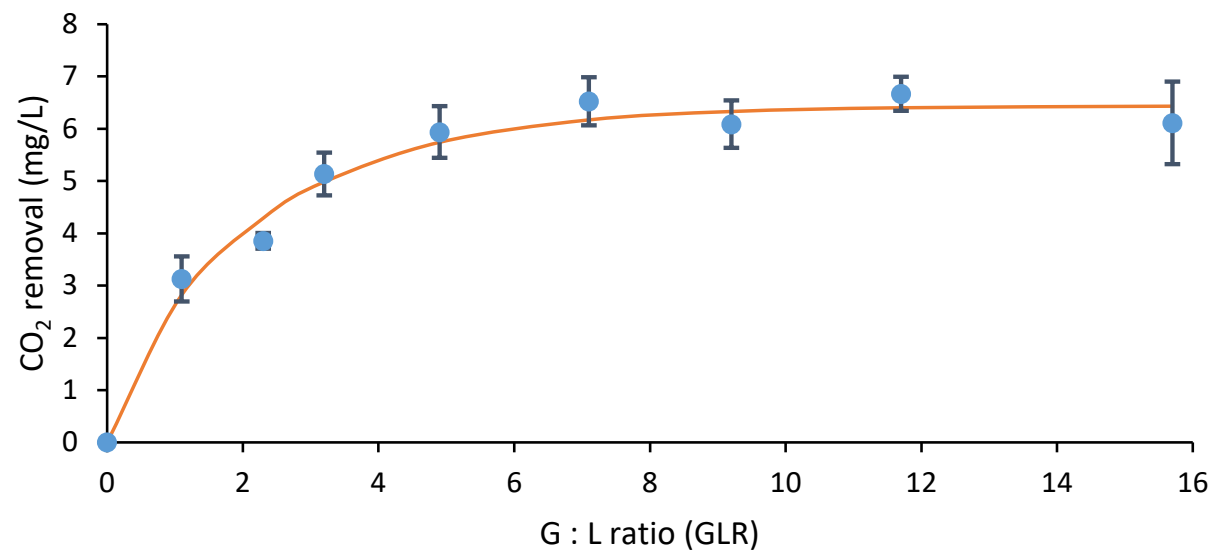

Fig. 2 Carbon dioxide removal from the water ((calculated from the difference in $\mathrm{CO}_{2}$ concentration between ingoing and outgoing air $\left(\Delta \mathrm{CO}_{2(\mathrm{~g})}\right)$ of the trickling filter)) in relation to the gas liquid ratio (GLR). The asymptotic equation of the line is:

$\mathrm{CO}_{2}$ removal from water $\left(\frac{m g}{L}\right)=6.44-5.82 *\left(0.648^{G L R}\right) ; \quad\left(\mathrm{R}^{2}=0.91\right)$.

\subsection{Carbon dioxide removal from water, based on water measurements}

Results on $\mathrm{CO}_{2}$ removal from the water by water measurements at different GLRs are presented in Table 6. For the tested GLRs mean alkalinity (Alk) in the inlet and outlet water of the TF were between 0.86 - $1.46 \mathrm{meq} / \mathrm{L}$ and between $0.83-1.42 \mathrm{meq} / \mathrm{L}$, respectively. By passing the TF, alkalinity decreased a little in the water, probably due to consumption by nitrifying bacteria, except for the tested GLRs 1.2 and 11.7 where a little increase was observed. Mean inlet and outlet $\mathrm{pH}$ values ranged between 7.02 7.12 and between $7.10-7.32$, respectively, and were always higher in the outlet water of the TF. The mean TIC concentration in the inlet and outlet water of the TF was between 25.8 - 54.3 and between 22.1 - $50.4 \mathrm{mg} \mathrm{CO} / \mathrm{L}$ respectively. The absolute amount of dissolved $\mathrm{CO}_{2}$ removed $\left(\Delta \mathrm{CO}_{2}\right)$ calculated from the measured TIC and $\mathrm{pH}$ in the inlet and outlet water of the TF was for the tested GLRs between 1.2-3.8 $\mathrm{mg} \mathrm{CO}_{2} / \mathrm{L}$.

Table 6 Effect of gas : liquid ratio (GLR) on $\mathrm{CO}_{2}$ removal from the water by calculation, using TIC and $\mathrm{pH}$ in the inlet and outlet water of the trickling filter. Values are mean $\pm \mathrm{SD}(\mathrm{n}=12)$ except for total inorganic carbon (TIC) measurements and $\mathrm{CO}_{2}(\mathrm{aq})$ where $\mathrm{n}=7$.

\begin{tabular}{|c|c|c|c|c|c|c|c|c|c|}
\hline \multirow[b]{2}{*}{$\begin{array}{l}\text { Water quality } \\
\text { parameters }\end{array}$} & \multirow[b]{2}{*}{ Unit } & \multicolumn{8}{|c|}{ G : L Ratio (GLR) } \\
\hline & & 1.2:1 & 2.3:1 & 3.2:1 & $5.0: 1$ & 7.1:1 & 9.2:1 & 11.7:1 & 15.7:1 \\
\hline Alk in ${ }^{11}$ & $\mathrm{meq} / \mathrm{L}$ & $1.32 \pm 0.0$ & $1.14 \pm 0.1$ & $0.86 \pm 0.1$ & $1.14 \pm 0.1$ & $1.46 \pm 0.1$ & $1.17 \pm 0.1$ & $1.13 \pm 0.1$ & $1.44 \pm 0.0$ \\
\hline Alk out & $\mathrm{meq} / \mathrm{L}$ & $1.35 \pm 0.1$ & $1.11 \pm 0.1$ & $0.83 \pm 0.1$ & $1.13 \pm 0.1$ & $1.42 \pm 0.0$ & $1.14 \pm 0.0$ & $1.18 \pm 0.1$ & $1.40 \pm 0.1$ \\
\hline Inlet $\mathrm{pH}$ & & $7.12 \pm 0.1$ & $7.02 \pm 0.1$ & $7.05 \pm 0.1$ & $7.02 \pm 0.1$ & $7.07 \pm 0.1$ & $7.05 \pm 0.1$ & $7.04 \pm 0.1$ & $7.06 \pm 0.1$ \\
\hline Outlet $\mathrm{pH}$ & & $7.24 \pm 0.0$ & $7.10 \pm 0.0$ & $7.14 \pm 0.0$ & $7.10 \pm 0.0$ & $7.27 \pm 0.0$ & $7.16 \pm 0.1$ & $7.15 \pm 0.0$ & $7.32 \pm 0.0$ \\
\hline Inlet TIC & $\mathrm{mg} \mathrm{CO}_{2} / \mathrm{L}$ & $53.4 \pm 1.5$ & $45.0 \pm 0.8$ & $25.8 \pm 1.5$ & $37.8 \pm 1.5$ & $54.3 \pm 1.4$ & $47.6 \pm 1.9$ & $26.8 \pm 3.2$ & $52.5 \pm 5.6$ \\
\hline Outlet TIC & $\mathrm{mg} \mathrm{CO}_{2} / \mathrm{L}$ & $49.5 \pm 1.4$ & $41.0 \pm 1.0$ & $22.1 \pm 1.7$ & $32.6 \pm 2.4$ & $50.4 \pm 1.5$ & $43.6 \pm 1.3$ & $22.4 \pm 3.4$ & $48.1 \pm 4.1$ \\
\hline \multirow[t]{2}{*}{$\Delta \mathrm{TIC}$ (method 2) } & $\mathrm{mg} \mathrm{CO}_{2} / \mathrm{L}$ & $3.9 \pm 0.6$ & $4.0 \pm 0.8$ & $3.7 \pm 0.8$ & $5.2 \pm 1.2$ & $4.0 \pm 0.8$ & $4.0 \pm 2.4$ & $4.4 \pm 0.6$ & $4.4 \pm 1.8$ \\
\hline & & \multicolumn{8}{|c|}{ Calculated dissolved $\mathrm{CO}_{2}(\mathrm{aq})$ using TIC and $\mathrm{pH}(\operatorname{method} 3)$} \\
\hline Inlet $\mathrm{CO}_{2}(\mathrm{aq})$ & $\mathrm{mgCO}_{2} / \mathrm{L}$ & $8.2 \pm 0.5$ & $7.7 \pm 0.9$ & $4.4 \pm 0.4$ & $7.2 \pm 0.4$ & $8.8 \pm 0.8$ & $8.4 \pm 0.4$ & $4.4 \pm 0.5$ & $8.5 \pm 1.0$ \\
\hline Outlet $\mathrm{CO}_{2}(\mathrm{aq})$ & $\mathrm{mgCO}_{2} / \mathrm{L}$ & $5.4 \pm 0.2$ & $6.1 \pm 0.6$ & $3.1 \pm 0.3$ & $5.1 \pm 0.5$ & $5.6 \pm 0.2$ & $5.8 \pm 0.1$ & $3.0 \pm 0.2$ & $4.7 \pm 0.5$ \\
\hline$\Delta \mathrm{CO}_{2}(\mathrm{aq})(\operatorname{method} 3)$ & $\mathrm{mgCO}_{2} / \mathrm{L}$ & $2.8 \pm 0.2$ & $1.6 \pm 0.3$ & $1.2 \pm 0.2$ & $2.1 \pm 0.7$ & $3.2 \pm 0.7$ & $2.7 \pm 0.4$ & $1.3 \pm 0.5$ & $3.8 \pm 0.7$ \\
\hline Relative $\mathrm{CO}_{2}(\mathrm{aq})$ removal & $\%$ & $34.3 \pm 1.4^{\mathrm{d}}$ & $20.9 \pm 1.9^{\mathrm{a}, \mathrm{b}}$ & $27.7 \pm 3.5^{\mathrm{b}, \mathrm{c}}$ & $29.2 \pm 9.2^{\mathrm{a}, \mathrm{b}, \mathrm{c}, \mathrm{d}}$ & $36.0 \pm 5.7^{\mathrm{b}, c, \mathrm{~d}, \mathrm{e}}$ & $31.4 \pm 2.8^{\mathrm{b}, \mathrm{c}, \mathrm{d}}$ & $29.8 \pm 9.5^{a, b, c, d, c}$ & $44.5 \pm 3.6^{\mathrm{e}}$ \\
\hline
\end{tabular}

1) Alk = alkalinity in meq $/ \mathrm{L} ;{ }^{2)}$ TIC is presented as $\mathrm{CO}_{2}(\mathrm{mg} / \mathrm{L})$. Row means with different superscript letters indicate significant differences $(\mathrm{p}<0.05)$ in the post hoc Games-Howell test. 


\subsection{Effect of GLRs on heat loss from the recirculating water}

The results of the effect of GLRs on heat loss from water passing the TF are presented in Table 7. Heat loss across the TF for the tested GLRs was determined under the following conditions: mean inlet water temperature of $27.0-27.5^{\circ} \mathrm{C}$; mean outlet water temperature of $26.9-27.4^{\circ} \mathrm{C}$; mean ingoing air temperature of $19.5-22.6{ }^{\circ} \mathrm{C}$; mean ingoing air relative humidity of $52.5-72.1 \%$. During this study, the inlet water temperature and the inlet air temperature were kept in a narrow range (Table 7). Relative inlet humidity differed per GLR treatment as it was not controlled during this study. Humidity differed per GLR as the outside climate varied during the 118 days experimental period. Mean outlet air temperature and humidity for the different GLRs was between $25.2-27.4^{\circ} \mathrm{C}$ and $98.0-100 \%$, respectively. The temperature of the outgoing air increased to a similar temperature as the inlet water, however, at lower GLRs the outgoing air temperature was 1 to $2^{\circ} \mathrm{C}$ lower as the inlet water temperature. The mean increase in air temperature $\left(\Delta\right.$ Temperature $_{\text {air }}$ ) and humidity $(\Delta$ Humidity) for the tested GLRs was between $3.7-7.2^{\circ} \mathrm{C}$ and $26.3-47.4 \%$ respectively. The mean barometric pressure for the tested GLRs was between 99.8-101.9 kPa. For the tested GLRs the calculated mean heat flux in the inlet and outlet air ranged from $291-5161$ and $547-8337 \mathrm{~kJ} / \mathrm{h}$, respectively. From the total mean heat loss by the vented air $(256-3177 \mathrm{~kJ} / \mathrm{h})$, mean latent heat loss was $247-2884 \mathrm{~kJ} / \mathrm{h}$ and mean sensible heat loss $9-293 \mathrm{~kJ} / \mathrm{h}$. Water loss to the vented air due to water evaporation in the TF was between $101-1184$ $\mathrm{g} / \mathrm{h}$. For the tested GLRs and the ambient experimental conditions the mean heat loss per $\mathrm{m}^{3}$ vented air was $28-40 \mathrm{~kJ} / \mathrm{m}^{3}$, per g $\mathrm{CO}_{2}$ removal $13-82 \mathrm{~kJ}$ and per $\mathrm{kg}$ feed $2-25 \mathrm{MJ} / \mathrm{kg}$. In Fig. 3 the effect of GLR on total, latent and sensible heat losses in the trickling filter are shown. From this figure linear relationships between GLR and the different heat losses can be observed. Fig. 4 shows that the heat loss per kg CO 2 removal increased together with the daily $\mathrm{CO}_{2}$ removal until the daily $\mathrm{CO}_{2}$ removal reaches a maximum plateau of on average $972 \mathrm{~g} \mathrm{CO}_{2} / \mathrm{d}$ at a GLR between 5 and 7.1.

Table 7. Effect of gas : liquid ratio (GLR) on heat loss across the trickling filter from the recirculating water. Values are means $\pm \mathrm{SD}(\mathrm{n}=12)$. Values represent data collected by continuous measuring during each tested GLR. Data of every $3 \mathrm{~h}$ for 2 days measuring in every GLR from 08:00 AM to 11:00 PM was used.

\begin{tabular}{|c|c|c|c|c|c|c|c|c|c|}
\hline \multirow[b]{2}{*}{$\begin{array}{l}\text { Air quality and } \\
\text { Energy parameters }\end{array}$} & \multirow[b]{2}{*}{ Unit } & \multicolumn{8}{|c|}{ G : L Ratio (GLR) } \\
\hline & & 1.2:1 & 2.3:1 & 3.2:1 & 5.0:1 & 7.1:1 & 9.2:1 & 11.7:1 & 15.7:1 \\
\hline Air flow & $\mathrm{m}^{3} / \mathrm{h}$ & $6.6 \pm 2.2$ & $14.8 \pm 0.3$ & $20.5 \pm 0.2$ & $31.5 \pm 0.3$ & $46.7 \pm 0.3$ & $63.7 \pm 1.3$ & $73.3 \pm 1.6$ & $99.2 \pm 0.2$ \\
\hline Inlet temperature water & ${ }^{\circ} \mathrm{C}$ & $27.2 \pm 0.4$ & $27.3 \pm 0.2$ & $27.0 \pm 0.1$ & $27.3 \pm 0.2$ & $27.4 \pm 0.4$ & $27.3 \pm 0.3$ & $27.4 \pm 0.3$ & $27.5 \pm 0.3$ \\
\hline Outlet temperature $_{\text {water }}$ & ${ }^{\circ} \mathrm{C}$ & $27.3 \pm 0.3$ & $27.3 \pm 0.2$ & $26.9 \pm 0.2$ & $27.3 \pm 0.3$ & $27.4 \pm 0.3$ & $27.3 \pm 0.3$ & $27.4 \pm 0.2$ & $27.4 \pm 0.3$ \\
\hline Inlet temperature $_{\text {air }}$ & ${ }^{\circ} \mathrm{C}$ & $20.5 \pm 3.2$ & $22.4 \pm 3.2$ & $19.5 \pm 3.4$ & $22.6 \pm 0.4$ & $22.1 \pm 0.3$ & $22.5 \pm 0.3$ & $19.8 \pm 1.4$ & $22.0 \pm 2.6$ \\
\hline Outlet temperature $_{\text {air }}$ & ${ }^{\circ} \mathrm{C}$ & $25.2 \pm 0.2$ & $26.2 \pm 0.2$ & $25.7 \pm 0.0$ & $26.8 \pm 0.2$ & $27.0 \pm 0.3$ & $27.1 \pm 0.2$ & $27.0 \pm 0.2$ & $27.4 \pm 0.3$ \\
\hline$\Delta$ Temperature $_{\text {air }}$ & ${ }^{\circ} \mathrm{C}$ & $4.6 \pm 0.6$ & $3.7 \pm 0.2$ & $6.2 \pm 0.2$ & $4.2 \pm 0.3$ & $4.9 \pm 0.3$ & $4.6 \pm 0.4$ & $7.2 \pm 0.4$ & $5.3 \pm 0.3$ \\
\hline Inlet humidity & $\%$ & $52.5 \pm 5.2$ & $69.2 \pm 5.2$ & $55.0 \pm 3.5$ & $66.9 \pm 2.2$ & $72.1 \pm 3.9$ & $71.9 \pm 2.8$ & $62.3 \pm 3.8$ & $71.7 \pm 3.7$ \\
\hline Outlet humidity & $\%$ & $100.0 \pm 0.0$ & $99.7 \pm 0.0$ & $99.6 \pm 0.0$ & $98.8 \pm 0.1$ & $98.7 \pm 0.1$ & $98.3 \pm 0.1$ & $98.2 \pm 0.2$ & $98.0 \pm 0.1$ \\
\hline$\Delta$ Humidity & $\%$ & $47.4 \pm 4.4$ & $30.5 \pm 1.6$ & $44.6 \pm 2.7$ & $31.9 \pm 2.1$ & $26.6 \pm 2.3$ & $26.5 \pm 2.8$ & $35.9 \pm 4.7$ & $26.3 \pm 3.0$ \\
\hline \multirow[t]{2}{*}{ Barometric pressure } & $\mathrm{kPa}$ & $101.1 \pm 0.2$ & $100.3 \pm 0.2$ & $101.8 \pm 0.1$ & $99.8 \pm 0.1$ & $101.2 \pm 0.2$ & $101.9 \pm 0.4$ & $100.0 \pm 0.3$ & $100.0 \pm 0.5$ \\
\hline & \multicolumn{9}{|c|}{ Calculated heat loss across the trickling filter } \\
\hline Inlet energy & $\mathrm{kJ} / \mathrm{h}$ & $291 \pm 29$ & $766 \pm 17$ & $799 \pm 14$ & $1620 \pm 37$ & $2426 \pm 58$ & $3381 \pm 91$ & $3099 \pm 132$ & $5161 \pm 113$ \\
\hline Outlet energy & $\mathrm{kJ} / \mathrm{h}$ & $547 \pm 62$ & $1179 \pm 23$ & $1596 \pm 22$ & $2587 \pm 38$ & $3859 \pm 53$ & $5279 \pm 89$ & $6039 \pm 156$ & $8337 \pm 125$ \\
\hline Total heat loss & $\mathrm{kJ} / \mathrm{h}$ & $256 \pm 42$ & $416 \pm 18$ & $798 \pm 26$ & $967 \pm 38$ & $1433 \pm 77$ & $1898 \pm 94$ & $2940 \pm 162$ & $3177 \pm 190$ \\
\hline Latent heat loss & $\mathrm{kJ} / \mathrm{h}$ & $247 \pm 40$ & $395 \pm 18$ & $742 \pm 28$ & $913 \pm 38$ & $1314 \pm 70$ & $1751 \pm 93$ & $2651 \pm 166$ & $2884 \pm 174$ \\
\hline Sensible heat loss & $\mathrm{kJ} / \mathrm{h}$ & $8.79 \pm 3$ & $20.66 \pm 3$ & $55.57 \pm 5$ & $53.26 \pm 8$ & $118.97 \pm 14$ & $145.98 \pm 22$ & $288.81 \pm 31$ & $292.81 \pm 24$ \\
\hline Evaporation & $\mathrm{g} / \mathrm{h}$ & $101 \pm 16$ & $161 \pm 7$ & $304 \pm 11$ & $374 \pm 15$ & $539 \pm 28$ & $719 \pm 38$ & $1088 \pm 68$ & $1184 \pm 71$ \\
\hline Heat loss/air flow & $\mathrm{kJ} / \mathrm{m}^{3}$ & $35.3 \pm 2.5$ & $28.0 \pm 1.0$ & $38.9 \pm .01$ & $30.6 \pm 1.0$ & $30.7 \pm 1.7$ & $29.8 \pm 1.6$ & $40.1 \pm 1.8$ & $32.0 \pm 1.9$ \\
\hline $\begin{array}{l}\text { Heat loss per } \mathrm{g} \mathrm{CO}_{2}{ }^{\mathrm{a}} \\
\text { uptake }\end{array}$ & $\mathrm{kJ} / \mathrm{g} \mathrm{CO} 2$ & $13.4 \pm 1.4$ & $17.0 \pm 1.0$ & $24.2 \pm 2.2$ & $26 \pm 2.0$ & $33.5 \pm 2.3$ & $46.4 \pm 4.9$ & $70.6 \pm 6.8$ & $82.1 \pm 10.9$ \\
\hline Heat loss per $\mathrm{kg}$ feed & $\mathrm{MJ} / \mathrm{kg}$ feed & $2.0 \pm 0.3$ & $3.3 \pm 0.2$ & $6.4 \pm 0.2$ & $7.7 \pm 0.3$ & $11.5 \pm 0.6$ & $15.2 \pm 0.8$ & $23.52 \pm 1.3$ & $25.4 \pm 1.5$ \\
\hline
\end{tabular}

${ }^{\mathrm{a}}$ For calculation of this term, the $\mathrm{CO}_{2}$ removal data have been used from table 5 . 


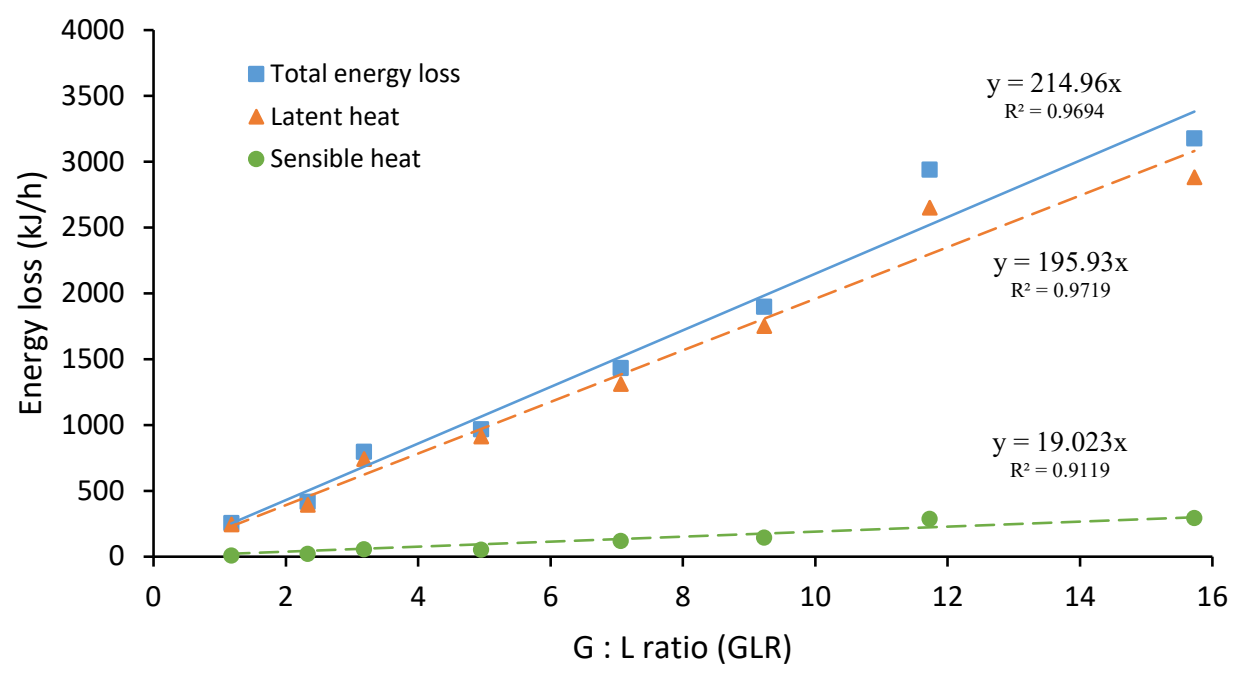

Fig. 3. The relationship between gas : liquid ratio (GLR) and total, latent, and sensible heat loss $(\mathrm{kJ} / \mathrm{h})$ across a trickling filter. The intercepts of the estimated trend lines were set at zero.

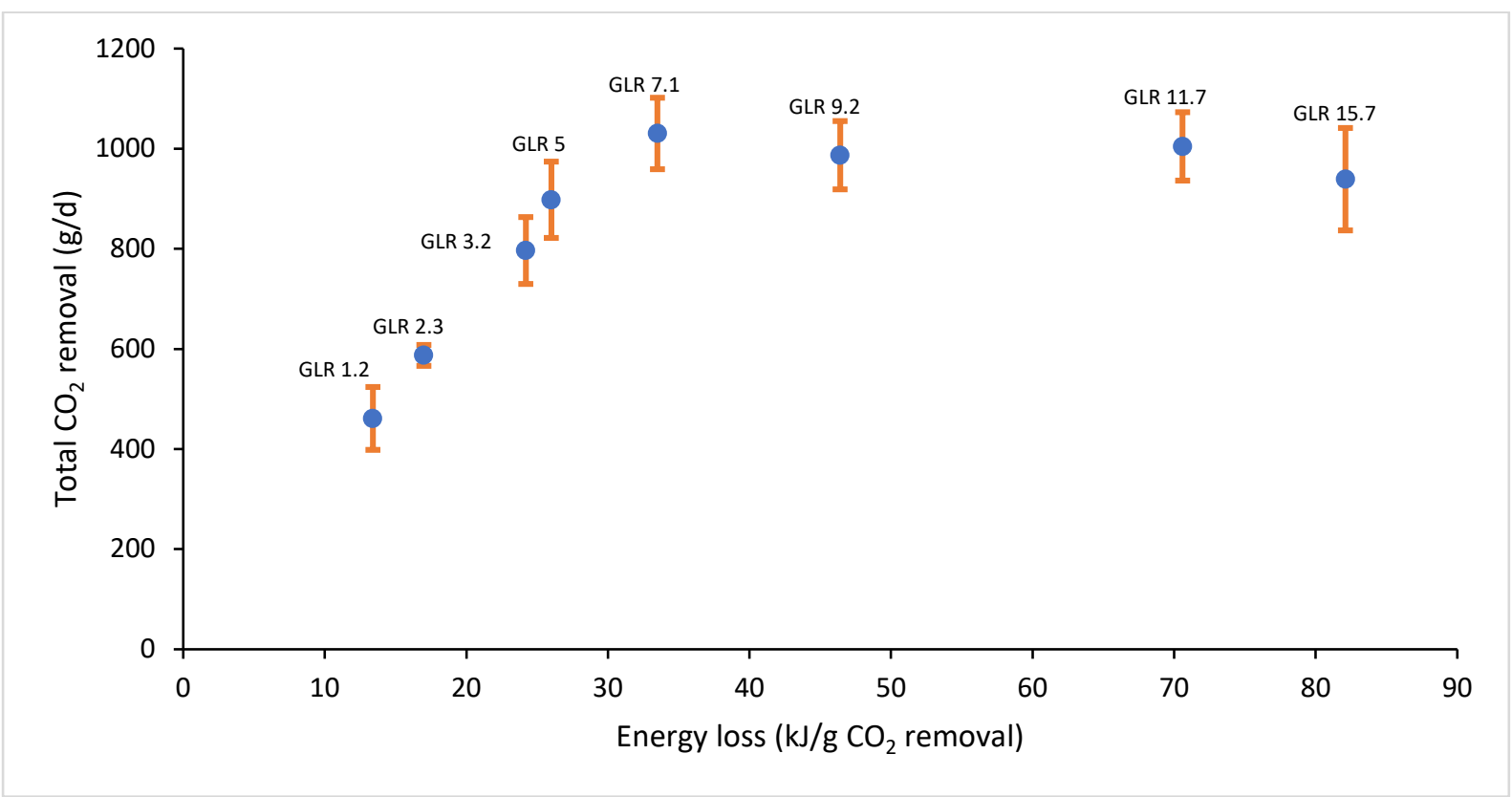

Fig. 4. Relationship between total energy loss (latent and sensible heat) per $\mathrm{g} \mathrm{CO}_{2}$ removed and the total amount of $\mathrm{CO}_{2}$ (aq) removed per day for each measured gas : liquid ratio (label) across the trickling filter. 


\section{Discussion}

In this chapter first the measured effect of GLR on $\mathrm{CO}_{2}$ removal from water is discussed, based on the air measurements, followed by a discussion on the differences we found in $\mathrm{CO}_{2}$ removal rate, when concentrations were measured in the influent and effluent of the water in the recirculation system. Finally, the results of the energy loss through ventilation in the trickling filter will be discussed.

\subsection{Carbon dioxide removal from water, based on air measurements}

The $\mathrm{CO}_{2}$ (aq) removal from the water, as measured from the $\mathrm{CO}_{2}(\mathrm{~g})$ concentrations in the inlet and outlet air of the trickling filter and the airflow rate, showed an asymptotic effect of GLR (Fig. 2). The asymptotic equation of the line is:

$\mathrm{CO}_{2}$ removal from water $\left(\frac{\mathrm{mg}}{\mathrm{L}}\right)=6.44-5.82 *\left(0.648^{G L R}\right)$

At low GLR, increasing the GLR had a large effect on $\mathrm{CO}_{2}$ removal, but with increasing GLRs the marginal effect was reduced, reaching a maximum $\mathrm{CO}_{2}$ removal rate of approx. $6.44 \mathrm{mg} / \mathrm{L}$ water at a GLR of approx. 7. Equation 1 has been fitted for the current experimental conditions with relatively low inlet $\mathrm{CO}_{2}$ concentrations $(<10 \mathrm{mg} / \mathrm{L})$ within the $\mathrm{pH}$-range $6.9-7.1$. Earlier $\mathrm{CO}_{2}$ stripping studies demonstrated that increased GLRs resulted in higher $\mathrm{CO}_{2}$ removal rates (Summerfelt et al., 2003; Summerfelt et al., 2000), as found in the present study. The data of $\mathrm{CO}_{2}(\mathrm{~g})$ uptake was comparable with other studies (Summerfelt et al., 2003; Summerfelt et al., 2000). Moreover, Table 5 and Fig. 2 shows that a GLR of at least 5.0 is needed for maximal $\mathrm{CO}_{2}$ stripping, which is consistent with the GLR of 5.1 found by Summerfelt et al. (2003). Our results showed that a GLR of 5.0 produced a relatively similar carbon dioxide removal compared with GLRs of 7.1, 9.2, 11.7, and 15.7 (Table 5, Fig. 2). Therefore, it can be concluded that, within the setup of our study, it will not be economically to provide a higher GLR than 5 , except when cooling of water is needed.

Moran (2010) has estimated the $\mathrm{CO}_{2}(\mathrm{~g})$ in the air through some assumptions and calculations in his research. The $\mathrm{CO}_{2}(\mathrm{~g})$ concentration in the ingoing and outgoing air of the degasser column was not measured in his study but it was measured by (Summerfelt et al., 2003; Summerfelt et al., 2000). As both studies were very comparable with our research, in this part we will compare our results with their studies. In the study of Moran (2010), the ventilation fan that was used to create counter current air flow (GLR 1.0 vs. 4.6) in the cascade column (1.6 m height) did not improve stripping efficiency. This conclusion does not fit with our results and neither with results from other studies (Grace and Piedrahita, 1994; Summerfelt et al., 2003; Summerfelt et al., 2000), in which similar results were found as in our study. Results from our study and from (Summerfelt et al., 2003; Summerfelt et al., 2000) demonstrate a strong relationship between air exchange rate and $\mathrm{CO}_{2}$ stripping efficiency. Summerfelt et al. (2000) reported that the relative $\mathrm{CO}_{2}(\mathrm{~g})$ concentration in the air increased with $290 \%$ and $68 \%$ for inlet water $\mathrm{CO}_{2}$ (aq) concentrations of $11.5-14.0 \mathrm{mg} / \mathrm{L}$ with a packing depth of $1.0 \mathrm{~m}$ and GLRs of 1.2 or 10, respectively. The GLRs 1.2 and 9.2 of our study have a similar relative air $\mathrm{CO}_{2}(\mathrm{~g})$ concentration increase, of $299 \%$ and $73 \%$, respectively.

\subsection{Comparison of $\mathrm{CO}_{2}$ removal, measured in air and water}

In this section, the differences we found between the three different methods to estimate $\mathrm{CO}_{2}$ removal from the water are discussed; method 1: by $\Delta \mathrm{CO}_{2}(\mathrm{~g})$ measured in the air (Table 5); method 2: by $\triangle \mathrm{TIC}$ measured in the water; method 3: by calculating $\Delta \mathrm{CO}_{2}$ in water using TIC and $\mathrm{pH}$ in the inlet and outlet water (Table 6). 
The $\mathrm{CO}_{2}$ that is stripped from the water will be taken up by the air going through the trickling filter. Therefore, this amount should approximately equal the difference in the influent and effluent TIC values (Colt et al., 2012; Grace and Piedrahita, 1994) and therefore we expected the 3 methods would show the same amount of $\mathrm{CO}_{2}$-removal and thus having lines that might be touching or overlapping and have the same trend and shape in Fig. 5. When we assume that no $\mathrm{CO}_{2}(\mathrm{~g})$ is formed from the carbonate pool inside the water and that $\mathrm{CO}_{2}(\mathrm{~g})$ production and bicarbonate consumption from bacterial activity in the trickling filter is negligible, the following equation should be valid:

$\Delta \mathrm{CO}_{2}$ stripped $\left(\mathrm{mg} / \mathrm{L}\right.$ as $\left.\mathrm{CO}_{2}\right)=\mathrm{CO}_{2}$ out air $-\mathrm{CO}_{2}$ in air $=\mathrm{TIC}$ in $-\mathrm{TIC}$ out $\left(\mathrm{mg} / \mathrm{L}\right.$ as $\left.\mathrm{CO}_{2}\right)=\mathrm{CO}_{2}$ in water $-\mathrm{CO}_{2}$ out water

From Fig. 5 it can be seen that the $\mathrm{CO}_{2}$ (aq) removal calculated by using TIC and $\mathrm{pH}$ has a lot more variation at the different GLRs than the $\mathrm{CO}_{2}(\mathrm{aq})$ removal determined by $\mathrm{CO}_{2}(\mathrm{~g})$ measured in the air. Furthermore $\triangle$ TIC does not really follow the curve as determined by $\Delta \mathrm{CO}_{2}$ (aq) removal based on the measured $\Delta \mathrm{CO}_{2}(\mathrm{~g})$ in the air. Calculated $\mathrm{CO}_{2}$ removal by using TIC and $\mathrm{pH}$ were generally lower than calculated from the air.

In this study $\triangle \mathrm{TIC}$ was calculated from TIC concentrations (as $\mathrm{mg} \mathrm{CO}_{2} / \mathrm{L}$ ) in the trickling filter inlet water (25.8 - 54.3 $\mathrm{mg} \mathrm{CO}_{2} / \mathrm{L}$ or $7.0-14.8 \mathrm{mg} \mathrm{C} / \mathrm{L}$ ) and outlet water (mean between 22.1-50.4 $\mathrm{mg} \mathrm{CO} / \mathrm{L}$ (6.0-13.7 mg C/L) (Table 6). The calculated $\mathrm{CO}_{2}$ concentration in the inlet water of the trickling filter was less than $10 \mathrm{mg} \mathrm{CO}_{2} / \mathrm{L}$ and varied from $4.4-8.8 \mathrm{mg} \mathrm{CO}_{2} / \mathrm{L}(1.2-2.4 \mathrm{mg} \mathrm{C} / \mathrm{L})$ (Table 6).

In a biofilter $\mathrm{CO}_{2}$ is produced by autotrophic- (nitrification) and heterotrophic metabolism (Ebeling et al., 2006). The $\mathrm{CO}_{2}$ production due to nitrification was calculated to range from $2.05-3.10 \mathrm{mg} / \mathrm{L}$ for the measured TAN removal $(0.35-0.53 \mathrm{mg}$ TAN/L; Table 3$)$ using the stoichiometric relationship of nitrification (5.85 $\mathrm{mg} \mathrm{CO}_{2}$ production per $\mathrm{mg}$ TAN consumed or $1.59 \mathrm{mg} \mathrm{C} / \mathrm{mg} \mathrm{TAN}$; Ebeling et al., 2006). This $\mathrm{CO}_{2}$ is produced by consuming $\mathrm{HCO}_{3}{ }^{-}$from the carbonate pool in the biofilter $(1.69 \mathrm{mgC}$ per mg TAN converted into $\mathrm{NO}_{3}-\mathrm{N}$ ). The stoichiometric relationship of nitrification shows (Ebeling et al., 2006) that nitrification removes a small amount of the consumed carbon $\left(\mathrm{HCO}_{3}^{-}\right)$from the carbonate pool inside the biofilter $\left(0.1 \mathrm{mg}\right.$ TIC/mg TAN consumed) and converts the consumed $\mathrm{HCO}_{3}{ }^{-}$mainly into $\mathrm{CO}_{2}$. Thus in theory our TIC measurements are slightly affected by the nitrification process.

However, our $\triangle \mathrm{TIC}$ removal can be significantly affected by the $\mathrm{CO}_{2}$ produced from the organic matter carbon pool in the biofilter due to heterotrophic bacterial metabolism. Summerfelt and Sharrer (2004) deduced by calculation a mean $\mathrm{CO}_{2}$ production of $2 \mathrm{mg} / \mathrm{L}$ by heterotrophic bacterial metabolism across their fluidised sand bed biofilter. This was done by measuring the oxygen consumption across their fluidised sand bed filter (mean oxygen consumption $3.8 \mathrm{mg} \mathrm{O}_{2} / \mathrm{L}$ and a measured mean TAN removal of $0.51 \mathrm{mg} / \mathrm{L} . \mathrm{CO}_{2}$ productions in their study could even be as high as $3.42 \mathrm{mg} / \mathrm{L}$ when the stoichiometry for heterotrophic metabolism in Ebeling et al. (2006) is used. Also heterotrophic bacterial metabolism consume $\mathrm{HCO}_{3}^{-}(0.86 \mathrm{mg} \mathrm{C}$ per mg TAN consumed (Ebeling et al., 2006)). However this is less when compared with nitrification.

Finally when assuming comparable biofilter performance conditions as in Summerfelt and Sharrer (2004) (a high feed load per $\mathrm{m}^{3}$ installed biofilter installed and a mean TAN removal of $0.35-0.53 \mathrm{mg} / \mathrm{L}$ in our study versus $0.51 \mathrm{mg}$ TAN/L in the study of Summerfelt and Sharrer (2004)) it can be concluded that $\mathrm{CO}_{2}$ removal (as $\mathrm{mg} \mathrm{CO} / \mathrm{L}$ ) calculated as $\triangle \mathrm{TIC}\left(\mathrm{TIC}_{\mathrm{in}}-\mathrm{TIC}_{\text {out }}\right)$ or from $\left(\mathrm{CO}_{2}\right.$ in water $-\mathrm{CO}_{2}$ out water $)$ calculated from TIC and $\mathrm{pH}$ will under estimate the actual $\mathrm{CO}_{2}$ removal as inorganic carbon is added to the carbonate pool in the biofilter by heterotrophic bacterial metabolism. The higher observed $\mathrm{CO}_{2}$ removal measured in air underpin this statement: e.g. for four GLRs $>5$ (GLRs for which max. $\mathrm{CO}_{2}$ removal is assumed) the mean $\Delta \mathrm{CO}_{2}(\mathrm{~g})$ is $6.4 \pm 0.3 \mathrm{mg} \mathrm{CO} / \mathrm{L}$ compared to a mean $\Delta \mathrm{TIC}$ of $4.2 \pm 0.2$ 
$\mathrm{mg} \mathrm{CO} / \mathrm{L}$. Therefore, Method 1 (the air $\mathrm{CO}_{2}$-measurement) is superior to the other two methods as this method provides information to calculate the actual $\mathrm{CO}_{2}$ removal across the $\mathrm{TF}$ as it incorporates also the removal of inorganic $\mathrm{CO}_{2}$ produced from organic matter inside the TF. Method 2 and 3 give an estimate of the apparent $\mathrm{CO}_{2}$ removal and may significantly underestimate the actual $\mathrm{CO}_{2}$ removal rates. Equation 2 should therefore be modified in:

$\mathrm{CO}_{2}$ out air $-\mathrm{CO}_{2}$ in air $>\mathrm{TIC}$ in $-\mathrm{TIC}$ out and also $>\mathrm{CO}_{2}$ in water $-\mathrm{CO}_{2}$ out water

The relationship of the $\mathrm{CO}_{2}$ (aq) removal calculated by using TIC and $\mathrm{pH}$ (method 3) seems to be even more scattered than the one determined based on $\triangle$ TIC (method 2). This could have been caused, at least for a part, by variations in the generation of dissolved $\mathrm{CO}_{2}$ from the carbonate pool in the water. Although this is a slow process, some $\mathrm{CO}_{2}$ might have been formed from the carbonate pool and this will cause an underestimation of the $\mathrm{CO}_{2}$ removal by stripping.

We could not find a real good reason for the highly scattered results from the water measurements others than the high variations in measurements. Accuracy of water measurements used to calculate the removal of $\mathrm{CO}_{2}$ from water in a TF can be affected by hydraulic lag issues (Colt and Maynard, 2019a, b). However, since we had tried to create steady-state conditions for carbon dioxide production by 24 hours continues feeding conditions (see material and methods, section 2.1), we assume the effect of hydraulic lag is small. Standard deviations in the TIC removal (method 2 and 3) could probably have been reduced if another method with a higher accuracy and precision would have been used to determine TIC (Dickson, 2007). Variations in the $\mathrm{CO}_{2}$ (aq) removal for each GLR determined based on $\Delta \mathrm{CO}_{2}(\mathrm{~g})$ in the air (method 1) were probably lower because of higher accuracy of measurements of the air sensors compared to the water sensors. Furthermore, the air quality parameters have been measured every 5 minutes continuously whereas $\mathrm{CO}_{2}(\mathrm{aq})$ removal in water (methods 2,3 ) was calculated from 3 hours sampling of TIC.

It should be noted that the 12 repeated measurements for each GLR were done within two subsequent days. This means that the repeated measurements of one GLR were not fully independent from each other. The consequence is that un-well control of constant inlet water quality parameters, i.e. pH, TIC, $\mathrm{CO}_{2}$ during the 118 days of the experimental period might have had an effect on the estimated $\mathrm{CO}_{2}$ removal in the water. Certainly, when inlet $\mathrm{CO}_{2}(\mathrm{aq})$ concentrations are relatively low (about $<10 \mathrm{mg} / \mathrm{L}$ ), then it is really difficult to accurately determine the relatively small change in concentrations from inlet to outlet. If we wanted to achieve full independency of our data we should have randomized all measurements of all the GLRs. That would have taken a tremendous amount of time, because with each change of GLR the system needs to adapt again. In a full randomized setup the standard deviations of the $\mathrm{CO}_{2}$ removal of each GLR would probably even have been larger than we found in our setup. 


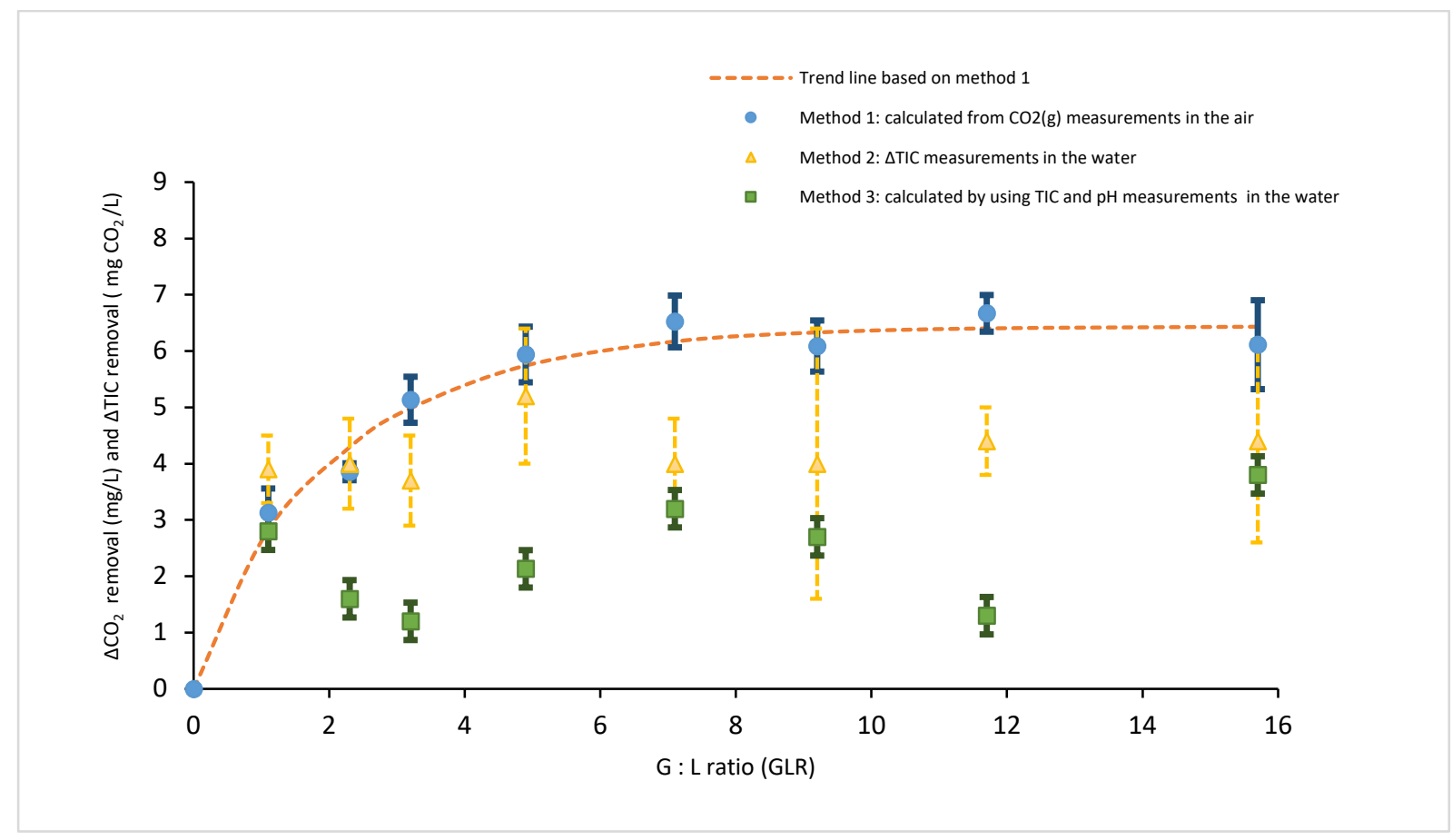

Fig. 5. Results of different methods to determine the $\mathrm{CO}_{2}$ removal $\left(\Delta \mathrm{CO}_{2}\right.$ in $\left.\mathrm{mg} / \mathrm{L}\right)$ from the water: Method 1: calculated from $\mathrm{CO}_{2}(\mathrm{~g})$ measurements in ingoing and outgoing air; Method 2: calculated from $\triangle$ TIC measurements in the inlet and outlet water; Method 3: calculated by using the TIC and $\mathrm{pH}$ measurements in the inlet and outlet water of the trickling filter.

\subsection{The effect of GL ratio on heat loss in the Trickling filter}

As the air flow increased with increasing GLRs, it was expected that the evaporation inside the trickling filter would increase, as well. The biggest part of energy loss is by latent heat due to evaporation. Latent and sensible heat losses linearly increased with GLR (Fig. 3). For the experimental conditions in this study the relationship between GLR and total heat loss $(\mathrm{kJ} / \mathrm{h})$ across a trickling filter is given by the following linear equation:

Energy loss $(\mathrm{kJ} / \mathrm{h})=214.96 * \mathrm{GLR} ; \quad\left(\mathrm{R}^{2}=0.97\right)$

Simultaneously, the absolute difference between latent and sensible heat increased with higher GLRs. The relative contribution of latent and sensible heat loss to total heat loss, however, remained approx. the same over the whole range, on average $91 \%$ of total heat loss was lost as latent heat and $9 \%$ as sensible heat.

Our results showed that the average energy loss per cubic meter of air for all GLRs was about $33.2 \pm$ $4.5 \mathrm{~kJ} / \mathrm{m}^{3}$. Energy loss at a GLR of 5 was $26.0 \mathrm{~kJ}$ per $\mathrm{g} \mathrm{CO}_{2}$ removed. The enthalpy of air can be calculated from the mixing ratio of air and water (mass of water vapour/mass of dry air) and temperature and air pressure. Changing the humidity and temperature will directly affect the enthalpy of air and an increase in GLR will increase the amount of air in contact with the water and water vapour pressure in the trickling filter. Therefore, evaporation increases and more energy will be drawn from the water. A lower vapour content of the ingoing air will give a higher difference in water pressure between air and water. Therefore, it can take up more moisture and this will increase energy loss from the system. 
During this study, the inlet water temperature and the inlet air temperature were kept in a narrow range (Table 7). Mean inlet water temperature and ingoing air temperature and humidity for the different GLRs was between $27.0-27.5^{\circ} \mathrm{C}, 19.5-22.6^{\circ} \mathrm{C}$, and $52.5-72.1 \%$, respectively. To consider the results of this research to be useful under farm conditions and not specific only for the conditions of this experiment, it is important that our results could be extrapolated to a wide range of the indoor climate parameters, i.e, air and water temperature, air humidity, and GLR in the farms.

In this study the temperature of the outgoing air increased to a similar temperature as the inlet water in the column of the trickling filter. However, at lower GLRs the outgoing air temperature was 1 to $2{ }^{\circ} \mathrm{C}$ lower as the inlet water temperature. This was probably caused by the fact that the temperature and humidity sensor of the outgoing air was not placed directly above the water column of the trickling filter, but approx. $1 \mathrm{~m}$ further in the exhaust duct. The average difference between the inlet water temperature and outgoing air temperature was $0.77{ }^{\circ} \mathrm{C}$. The average measured outgoing relative humidity in the trickling filter was $98-100 \%$. Hence, the outgoing air temperature is assumed to equal the inlet water temperature and the relative humidity in the outgoing air is assumed to equal $100 \%$. With these assumptions, results of heat losses measured within our experiment can be extrapolated to other air conditions of the ingoing air with the thermodynamic model written in MATLAB based on Mollier functions (ASHRAE, 2009). The results of these calculations are compared with the measured values within our experiment in fig. 6 . This comparison shows that measured and calculated values are very close. The regression coefficient is a bit lower than 1 , probably mainly caused by the fact that the sensor was not placed directly above the water column of the trickling filter, causing that some heat was already transferred by the duct wall.

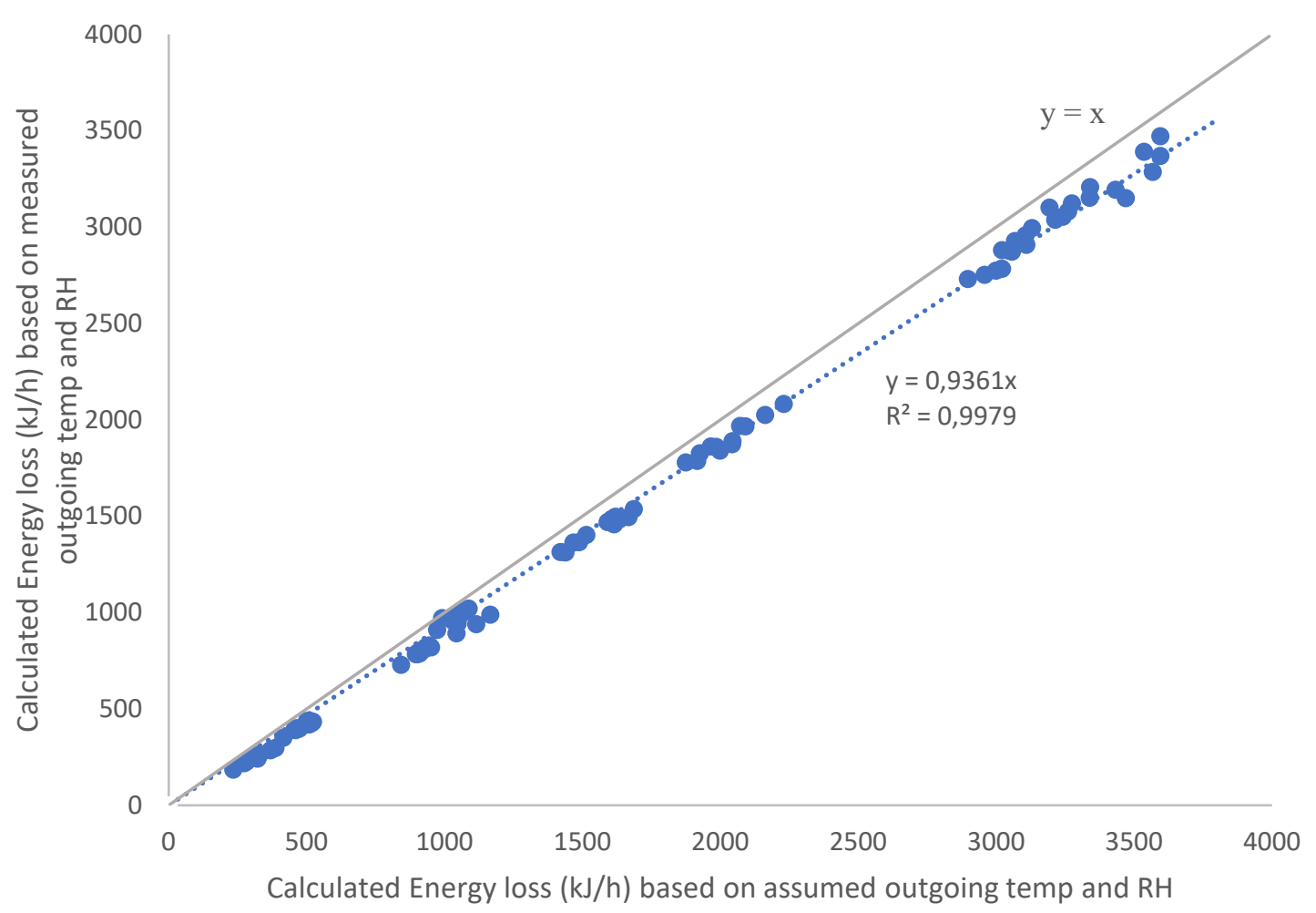

Fig. 6. $\mathrm{Y}=\mathrm{X}$ relationship between calculated energy loss by measured outgoing air temperature and humidity (Y) and assumed outgoing air temperature (equal to incoming water temperature) and humidity $(100 \%)$ in the trickling filter column. The intercept of the estimated trend line was set at zero. 
Thus, as experiments have been performed by lots of measured parameters and a narrow range of water and air temperature and humidity in the current experiments, the previously mentioned assumptions can be projected to farm conditions to lower the number of measurement parameters for different indoor climates. Therefore, the modified equation (4) is suggested for calculating energy loss for a wide range of indoor climates:

Energy loss $(\mathrm{kJ} / \mathrm{h})=2797.52+229.86 *(\mathrm{GLR})-123.24 *\left(\mathrm{~T}_{\text {air-in }}\right)-2.09 *\left(\mathrm{RH}_{\text {in }}\right) ; \quad\left(\mathrm{R}^{2}=0.98\right)$

In conclusion, to prevent accumulation of $\mathrm{CO}_{2}$ in recycling water and also in the ambient building air, the indoor air should have a sufficient replacement rate. By venting the air through the trickling filter free $\mathrm{CO}_{2}$ is extracted from the recirculating water. But with that a considerable amount of heat is lost, and that might cause higher energy costs. Part of this heat loss can be recovered by installing an air heat exchanger on top of the trickling filter or scrubbing the outlet air in a contact column tower with a strong base, i.e. sodium hydroxide, and recirculate this air into the building. Except for pumping costs and building space, air recycling through a scrubber or washing unit can reduce the heating or cooling demand (Summerfelt et al., 2000).

\section{Conclusions}

In order to optimize the energy loss and $\mathrm{CO}_{2}$ removal for the operational control of aquaculture recirculation water by a forced ventilated trickling filter, we conducted an experiment with different gas : liquid ratios (GLRs) in an super intensive African catfish RAS at $27^{\circ} \mathrm{C}$. The following can be concluded from this study:

(1) The $\mathrm{CO}_{2}$ removal rate, measured in the air phase shows a strong relationship with GLR. The relationship could be described as an asymptotic curve with the following equation $\mathrm{CO}_{2}$ removal from water $\left(\frac{\mathrm{mg}}{\mathrm{L}}\right)=6.44-5.82\left(0.648^{G L R}\right) ;\left(\mathrm{R}^{2}=0.91\right)$. Above a GLR of 5 heat loss will increase without significant additional $\mathrm{CO}_{2}$ removal (for low influent $\mathrm{CO}_{2}$ concentrations (i.e. $<10 \mathrm{mg} / \mathrm{L}$ )).

(2) Energy loss increases linearly with increasing GLR. Over the whole range, on average $91 \%$ of total heat is lost as latent heat and $9 \%$ as sensible heat. Energy loss at a GLR of 5 is, under our experimental conditions, $26.0 \mathrm{~kJ}$ per $\mathrm{g} \mathrm{CO}_{2}$ removed.

\section{Acknowledgements}

The authors acknowledge Johan Ploegaert, Menno ter Veld, Wian Nusselder, Ronald Booms, Eef Lovink and Tino Leffering for their support during the water quality analysis, Tom van der Zalm for installation of the data logger and Marc Verdegem for his assistance during the statistical analysis. Special thanks are due to Chris Verstege for his involvement during the sampling periods. We also thank three reviewers for their valuable comments and improving this manuscript. 


\section{References}

Abril, G., Bouillon, S., Darchambeau, F., Teodoru, C.R., Marwick, T.R., Tamooh, F., Ochieng Omengo, F., Geeraert, N., Deirmendjian, L., Polsenaere, P., Borges, A.V., 2015. Technical Note: Large overestimation of $\mathrm{pCO} 2$ calculated from $\mathrm{pH}$ and Alkalinity in acidic, organic freshwaters. Biogeosciences 12, 67-78.

ASHRAE, 2009. ASHRAE Handbook - Fundamentals (SI Edition). American Society of Heating, Refrigerating and Air-Conditioning Engineers, Inc. , Atlanta, USA.

Colt, J., Bouck, G., 1984. Design of packed columns for degassing. Aquacultural Engineering 3, 251-273.

Colt, J., Lamoureux, J., Patterson, R., Rogers, G., 2006. Reporting standards for biofilter performance studies. Aquacultural Engineering 34, 377-388.

Colt, J., Maynard, D., 2019a. Correction of metabolic parameters and unit process performance data - Part II : Comparison of analytical approaches. Aquacultural Engineering 87, 102019.

Colt, J., Maynard, D., 2019b. Correction of metabolic parameters and unit process performance data. Part I. derivation of equations. Aquacultural Engineering 86, 101999.

Colt, J., Watten, B., Pfeiffer, T., 2012. Carbon dioxide stripping in aquaculture. Part 1: Terminology and reporting. Aquacultural Engineering 47, 27-37.

Díaz, V., Ibáñez, R., Gómez, P., Urtiaga, A.M., Ortiz, I., 2012. Kinetics of nitrogen compounds in a commercial marine Recirculating Aquaculture System. Aquacultural Engineering 50, 20 27.

Dickson, A.G., Sabine, C.L., Christian, J.R, 2007. Guide to best practices for ocean CO2 measurements, PICES Special Publication, Sidney, British Columbia, p. 176.

Ebeling, J.M., Timmons, M.B., Bisogni, J.J., 2006. Engineering analysis of the stoichiometry of photoautotrophic, autotrophic, and heterotrophic removal of ammonia-nitrogen in aquaculture systems. Aquaculture 257, 346-358.

Eding, E.H., Kamstra, A., Verreth, J.A.J., Huisman, E.A., Klapwijk, A., 2006. Design and operation of nitrifying trickling filters in recirculating aquaculture: A review. Aquacultural Engineering 34, 234-260.

Ellis, R.P., Urbina, M.A., Wilson, R.W., 2017. Lessons from two high CO2 worlds - future oceans and intensive aquaculture. Global Change Biology 23, 2141-2148.

Fivelstad, S., 2013. Long-term carbon dioxide experiments with salmonids. Aquacultural Engineering 53, 40-48.

Grace, G., Piedrahita, R., 1993. Carbon dioxide control with a packed column aerator. Techniques for Modern Aquaculture. American Society of Agricultural Engineers, Saint Joseph, MI, 496-505.

Grace, G., Piedrahita, R., 1994. Carbon dioxide control. Dev. Aquacult.fish. sci. 27, 209-234.

Hackney, G.E., Colt, J.E., 1982. The performance and design of packed column aeration systems for aquaculture. Aquacultural Engineering 1, 275-295.

Heinsbroek, L.T.N., Kamstra, A., 1990. Design and performance of water recirculation systems for eel culture. Aquacultural Engineering 9, 187-207.

Kamstra, A., van der Heul, J.W., Nijhof, M., 1998. Performance and optimisation of trickling filters on eel farms. Aquacultural Engineering 17, 175-192.

Khan, J.R., Johansen, D., Skov, P.V., 2018. The effects of acute and long-term exposure to $\mathrm{CO}_{2}$ on the respiratory physiology and production performance of Atlantic salmon ( Salmo salar ) in freshwater. Aquaculture 491, 20-27.

Kvamme, K., Fivelstad, S., Handeland, S.O., Bergheim, A., 2018. Water flow and diurnal variation in metabolite production rates of Atlantic salmon ( Salmo salar L.) post-smolt. Aquaculture Research 50, 323-330.

Moran, D., 2010. Carbon dioxide degassing in fresh and saline water. I: Degassing performance of a cascade column. Aquacultural engineering 43, 29-36. 
Mota, V.C., Nilsen, T.O., Gerwins, J., Gallo, M., Ytteborg, E., Baeverfjord, G., Kolarevic, J., Summerfelt, S.T., Terjesen, B.F., 2019. The effects of carbon dioxide on growth performance, welfare, and health of Atlantic salmon post-smolt (Salmo salar) in recirculating aquaculture systems. Aquaculture 498, 578-586.

Murray, D.S., 2014. Effects of Biomass in Recirculating Aquaculture Water Heating and Cooling Systems. Master thesis-Rensselaer Polytechnic Institute, Hartford, CT, USA.

Noble, C., Kankainen, M., Setälä, J., Berrill, I.K., Ruohonen, K., Damsgård, B., Toften, H., 2012. The Bio-Economic Costs and Benefits of Improving Productivity and Fish Welfare in Aquaculture: Utilizing CO2 stripping Technology in Norwegian Atlantic Salmon Smolt Production. Aquaculture Economics \& Management 16, 414-428.

Roques, J.A.C., Schram, E., Spanings, T., van Schaik, T., Abbink, W., Boerrigter, J., de Vries, P., van de Vis, H., Flik, G., 2015. The impact of elevated water nitrite concentration on physiology, growth and feed intake of African catfishClarias gariepinus(Burchell 1822). Aquaculture Research 46, 1384-1395.

RSPCA, 2018a. RSPCA welfare standards for farmed Atlantic salmon

RSPCA, 2018b. RSPCA welfare standards for farmed rainbow trout.

Santos, G.A., Schrama, J.W., Capelle, J., Rombout, J.H.W.M., Verreth, J.A.J., 2013. Effects of dissolved carbon dioxide on energy metabolism and stress responses in European seabass (Dicentrarchus labrax). Aquaculture Research 44, 1370-1382.

Schram, E., Roques, J.A., Abbink, W., Yokohama, Y., Spanings, T., de Vries, P., Bierman, S., van de Vis, H., Flik, G., 2014. The impact of elevated water nitrate concentration on physiology, growth and feed intake of African catfish $\mathrm{C}$ larias gariepinus (Burchell 1822). Aquaculture research 45, 1499-1511.

Schram, E., Roques, J.A.C., Abbink, W., Spanings, T., de Vries, P., Bierman, S., de Vis, H.v., Flik, G., 2010. The impact of elevated water ammonia concentration on physiology, growth and feed intake of African catfish (Clarias gariepinus). Aquaculture 306, 108-115.

Summerfelt, S., Bebak-Williams, J., Tsukada, S., 2001. Controlled systems: water reuse and recirculation. American Fisheries Society, Bethesda, Maryland, pp. 285-396

Summerfelt, S.T., Davidson, J., Waldrop, T., 2003. Evaluation of full-scale carbon dioxide stripping columns in a coldwater recirculating system. Aquacultural Engineering 28, 155-169.

Summerfelt, S.T., Sharrer, M.J., 2004. Design implication of carbon dioxide production within biofilters contained in recirculating salmonid culture systems. Aquacultural Engineering 32, 171-182.

Summerfelt, S.T., Vinci, B.J., Piedrahita, R.H., 2000. Oxygenation and carbon dioxide control in water reuse systems. Aquacultural Engineering 22, 87-108.

Terjesen, B.F., Summerfelt, S.T., Nerland, S., Ulgenes, Y., Fjæra, S.O., Megård Reiten, B.K., Selset, R., Kolarevic, J., Brunsvik, P., Bæverfjord, G., Takle, H., Kittelsen, A.H., Åsgård, T., 2013. Design, dimensioning, and performance of a research facility for studies on the requirements of fish in RAS environments. Aquacultural Engineering 54, 49-63.

Timmons, M.B., Ebeling, J.M., 2010. Recirculating Aquaculture System, 2nd ed. Cayuga Aqau Ventures LLC, Ithaca, NY.

Vinci, B.J., Summerfelt, S.T., Creaser, D.A., Gillette, K., 2004. Design of partial water reuse systems at White River NFH for the production of Atlantic salmon smolt for restoration stocking. Aquacultural Engineering 32, 225-243.

Vinci, B.J., Timmons, M.B., Summerfelt, S.T., Watten, B.J., 1998. Carbon Dioxide Control in Intensive Aquaculture: Version 2.1: User's Guide and Source Code. Conservation Fund, Arlington, VA.

Watten, B., Colt, J., Boyd, C., 1991. Modeling the effect of dissolved nitrogen and carbon dioxide on the performance of pure oxygen absorption systems, Fisheries Bioengineering Symposium: American Fisheries Society Symposium 10, p. 474. 
